\title{
The medium is the message: learning channels, financial literacy, and stock market participation
}

\author{
Cecilia Hermansson ${ }^{\mathrm{a}}$ Sara Jonsson $^{\mathrm{b}} \quad \mathrm{Lu} \mathrm{Liu}^{\mathrm{c}}$
}

June 2021

\begin{abstract}
This paper investigates the effects of learning channels on stock market participation. More specifically, we investigate the direct effects of learning about financial matters from one's private network, financial advisors, and the media, as well as the moderating effects of financial literacy on the relationship between learning from these channels and stock market participation. Analyzing a unique cross-section data that combine survey data and bank register data on individual retail investors, we find that media is the only learning channel that increases the likelihood of owning stocks and the portfolio share invested in stocks. We also find that financial literacy has a significant moderating effect: Interactions point to the joint importance of learning from media and financial literacy for individuals' stock market participation. Our findings suggest implications to policymakers when designing financial education programs.
\end{abstract}

Keywords: stock market participation, learning channels, private network, financial advisors, media, financial literacy

\footnotetext{
${ }^{a}$ Division of Real Estate Economics and Finance, KTH Royal Institute of Technology; Email: cecilia.hermansson@abe.kth.se.

b Stockholm Business School, Stockholm University; Email: sara.jonsson@ sbs.su.se.

c Stockholm Business School, Stockholm University, and Knut Wicksell Centre for Financial Studies, Lund University; Email: lu.liu@sbs.su.se.
} 


\section{Introduction}

The literature on household finance has paid increasing attention to factors that affect individuals' investments in stocks. Various papers show that individuals with higher financial literacy are more likely to participate in equity markets (Christelis, Jappelli, and Padula 2010; Liao et al., 2017; Van Rooij, Lusardi, and Alessie, 2011; Yoong, 2011). The ability to understand investments and increased financial sophistication reduce cost barriers, encouraging participation (Jappelli and Padula, 2013). The positive correlation between financial literacy and probability of stock market participation has driven policymakers' efforts to increase financial literacy through financial education. The effects of such efforts are, however, not clear (Fernandes, Lynch, and Netemeyer, 2014; Lusardi, 2019; Willis, 2011). Recent studies, therefore, call for more research on how individuals learn about financial matters (Hastings, Madrian, and Skimmyhorn, 2013). In this study, we investigate the relevance of three learning channels: private networks (i.e., family and friends), financial advisors, and media (i.e., newspapers, television, and internet sites) for individuals' stock market participation (stock ownership and portfolio shares in stocks).

The existing literature shows that investors' interaction with, or accessibility to certain information channels alter financial behaviors. Several studies find that interactions in one's social network affect stock market participation (Brown et al., 2008; Girshina, Mathä, and Ziegelmeyer, 2019; Haliassos, Jansson, and Karabulut, 2020; Hong, Kubik, and Stein, 2004). Such effect can be explained by cheaper information sharing, leading to reduced fixed participation costs. The strength of the ties does however matter to the extent of this effect: weak ties plays the role of transmitting non-redundant information, thus having a positive effect on stock market participation, while strong ties have no such effect (Changwony, Campbell, and Tabner, 2015). Moreover, professional financial advisors could potentially provide cost reducing information. Studies however find that financial advisors are incentivized to cater to the interests of their employer (e.g., Inderst and Ottaviano, 2009; Foerster et al., 2017). Thus, information might be biased towards alternative financial products. Furthermore, media offers a large variety of information and may therefore provide information that is relevant and non-redundant to the individual, resulting in reduced participation costs. Previous studies show that media is effective in transmitting information about financial matters (e.g. Berg and Zia, 2017; Hu et al., 2020). 
The existing literature relies on measures of investors' interaction with, or accessibility to, certain information channels (e.g., family and friends, financial professionals, or financial news media) and, therefore, assumes that learning takes place during the interaction. The mechanism by which the three information channels affect stock market participation is not completely known. We extend the literature by showing the explicit informational relevance of each learning channel to stock market participation. Our measures of learning channels are elicited from survey respondents' ratings of the importance of each channel for learning financial and economic matters. Therefore, we capture the source's capacity to provide information that in turn reduces participation costs.

While controlling for a number of individual characteristics, including risk-tolerance, wealth, and family status, our results indicate that media is an important learning channel in the context of stock market participation. Learning about financial markets and economic matters through media positively associates with stock ownership, as well as the share of the portfolio invested in stocks. An increase in learning through media from the lowest extent to the highest extent is, on average, associated with an increase of 11 percentage points (pp) in the probability of owning stocks (the sample stock market participation rate is about 27\%) and an increase of 6 $\mathrm{pp}$ in portfolio shares invested in stocks conditional on owning stocks (the sample mean of portfolio share in stocks conditional on owning stocks is only 5.9\%). In contrast, learning from private networks or financial advisors has an insignificant effect on stock ownership and portfolio shares in stocks.

Research within educational psychology suggests that the effects of learning are strongly influenced by the individual's current knowledge (Ausubel, Novak, and Hanesian, 1968; Biggs 2011). Hence, it could be assumed that the effects of the learning channels on stock market participation are moderated by financial literacy. Accordingly, our analyses uncover evidence on the role of financial literacy in moderating the relation between learning channels and decision making, identifying either a reinforcing effect, or lack thereof, of financial literacy on the importance of the learning channels. We find a strong joint importance of learning from media and financial literacy for investing in stocks: The likelihood of participating in the stock market, and portfolio shares in stocks, increases with one's extent of learning from media only if the individual has high financial literacy. Conversely; the likelihood of participating in the stock market and portfolio shares in stocks increase with financial literacy only if the individual learns from media. For individuals with high financial literacy, an increase of learning through media from the lowest extent to the highest extent is associated with an increase of $13 \mathrm{pp}$ in the 
probability of owning stocks and an increase of $12 \mathrm{pp}$ in portfolio shares in stocks (conditional on owning stocks). For individuals with low financial literacy, learning through media has little association with stock ownership and portfolio shares in stocks. In contrast to learning through media, we find that the association between learning through one's private network or financial advisors and stock market participation is not moderated by financial literacy.

Our study contributes to the existing literature in two major aspects. First, our study explicitly measures the importance of specific channels for investors when learning about financial and economic matters, rather than using the interaction with the channels as proxies. The deviation of our finding from the findings in the existing literature indicates that learning about financial and economic matters from a specific channel is likely a different construct from interacting with that channel. For example, while prior studies find social interactions to increase stock market participation (e.g., Brown et al., 2008; Hong, Kubik, and Stein, 2004), we show that learning from family and friends about financial and economic matters is not associated with stock market participation or portfolio shares in stocks. Indeed, Balloch, Nicolae, and Philip (2015) argue that, when literacy is accounted for, sociability is no longer significant for participation.

Second, our study contributes to the discussion on whether and how financial literacy and financial education enhance households' financial decision-making (e.g., Balloch, Nicolae, and Philip, 2015; Fernandes, Lynch, and Netemeyer, 2014; Van Rooij, et al., 2011; Willis, 2011). To the best of our knowledge, our study is the first one that investigates how the relationship between learning channels and stock market participation is moderated by financial literacy. Our results provide important implications for policymakers when designing financial education programs. Our finding about the strong joint importance of learning through media and financial literacy indicates that policymakers should simultaneously promote both access to financial media and online financial information and financial education if they want to enhance direct stock market participation.

We structure the paper as follows. First, we review previous literature on the effects of private networks, financial advisors, and media on individuals' financial decision-making. We then describe the data and measurements used, followed by empirical analyses. The final section concludes.

\section{Literature review}


On an aggregate level, social ties may give access to information that reduces fixed stock market participation costs, thereby enhancing stock market participation (Brown et al., 2008; Changwony, Campbell, and Tabner, 2015; Georgarakos and Pasini, 2011; Hong, Kubik, and Stein, 2004; Liang and Guo, 2015). The social network theory, however, makes a clear distinction between weak ties, i.e., ties with acquaintances who one meets only occasionally, and strong ties, i.e., ties with family and close friends (Granovetter, 1973). While weak ties play a role in transmitting unique and nonredundant information across otherwise largely disconnected segments of social networks (Granovetter, 2005), strong ties to cohesive contacts can lead to a deficiency in acquiring new information and cognitive lock-in. Empirical studies on social interaction and stock market participation, however, generally make no distinction between tie strength (e.g., Hong, Kubik, and Stein, 2004; Georgarakos and Pasini, 2011). A notable exception is Changwony, Campbell, and Tabner (2015), who show that weak ties (being active in social groups) and strong ties (talking to neighbors) differ in how social interaction influences stock market participation: Weak ties affect stock market participation, while strong ties have no effect on participation. A possible explanation for these findings could be that information obtained from strong ties is redundant, noisy, and lacks in quality, and that the instrumental value of social ties depends on the match between the information needed by the individual and the resources she can access through her contacts. Hence, the effect of learning from ones' private network (family and friends) on stock market participation is expected to be small.

Information provided by financial advisors could lower cost barriers and encourage participation. The literature shows that financial advisors may exert substantial influence over their clients' asset allocation (e.g., Foerster et al., 2017). Financial advisors are, however, incentivized by commissions earned on recommended financial products. Thus, advice may be biased when financial advisors act as sellers of financial products (Inderst and Ottaviano, 2009). Christoffersen, Evans, and Musto (2013), Egan (2019), Hackethal, Haliassos, and Japelli (2012), Hoechle et al. (2018), and Mullainathan, Noeth, and Schoar (2012) use a variety of empirical strategies to show that brokers are more likely to recommend high-commission products. Advised portfolios commonly contain significantly less equity and more fixed income, and more mutual funds than securities (Kramer, 2016). This evidence may suggest that information obtained from financial advisors does not decrease participation costs to a large extent. Hence, it can be expected that learning from financial advisors has limited effect on stock market participation, specifically on direct stock market participation. 
There is increasing evidence that media (i.e., television, printed newspapers online news sites, and websites) is an effective medium to transmit information about financial matters. Berg and Zia (2017) find that educational commercials improve debt management. Hu et al. (2020) provide evidence that business TV helps households avoid some of the costliest financial mistakes related to mortgage refinancing. Engelberg and Parsons (2011) show that trades by individual investors located in various U.S. cities respond to business news coverage by local newspapers distributed in these cities. Dougal et al. (2012) find that the identity of Wall Street Journal columnists is a predictor of the next-day return on the Dow Jones Industrial Average. Peress (2014) further shows that newspapers causally affect investors' trading behavior. Explanations to these effects of media include cost effectiveness in terms of getting access to a broad spectrum of information, including information that is non-redundant, timely, and relevant. Furthermore, the media facilitates individuals' active choices of which items to view, resulting in more customized content. Hence, information obtained from media should have potential to reduce participation costs and we therefore expect that learning from media has a positive effect on stock market participation.

We extend previous findings in two ways. First, we focus on the three sources -private networks (family and friends), financial advisors, and media- as learning channels, examining their comparable effects on stock market participation. Extensive research within educational psychology points to the relevance of individual's current level of knowledge for effective learning processes (Ausbuel, Novak and Henesian, 1968). The amount and quality of current knowledge positively influence both knowledge acquisition and the capacity to apply higherorder cognitive problem-solving skills (Biggs, 2011). Trying to learn something without having adequate prior knowledge makes it difficult to relate the new information to existing knowledge (Tobias, 1994). We therefore also hypothesize that the effect of learning from the various channels on stock market participation is moderated by the individual's level of financial literacy. ${ }^{\mathrm{d}}$

\footnotetext{
${ }^{\mathrm{d}}$ Von Gaudecker (2015) uncovers an important interaction of financial literacy and financial advice in the decision-making process. The return loss of households that seek advice either in their private network (with family and friends) or from professionals does not vary with financial literacy. Among households making autonomous decisions, the distribution of the return loss looks very similar only if they are endowed with the maximum level of financial literacy.
} 


\section{Data}

Data are collected from one of Sweden's largest retail banks (the Bank, hereafter) with a market share of approximately $20 \%$ of the Swedish retail market and a client structure similar to the other three equally large banks. We collected two types of data: anonymized data from the Bank's register of individual retail customers (register data) and data from a survey sent to the Bank's retail customers included in the register sample (survey data). In the spring of 2013, we drew a random sample of 90,528 customers from the Bank's 2,254,420 Swedish customers. The conditions for including a customer in the sample was that the customer had an engagement with the Bank and was 18 years or older. The register data include individual-level demographic and socioeconomic data (age, gender, geographical location, income, financial assets, loans, and mortgages) collected in December 2013 and March 2016. We use register data collected in December 2013 in the main analysis. Register data from March 2016 is used in the robustness analysis.

We sent a questionnaire by post in the spring of 2013 to all customers in the register sample. An academic institution was the sender - and also the receiver of the responses - in order to achieve independence from the Bank. No reminders were sent. 16,062 respondents returned the survey yielding a response rate of $17.7 \%$. In the survey, the respondents were asked to answer questions related to financial literacy and rate to what extent they learn about financial and economic matters from their private networks (i.e., family and friends), financial advisors (i.e., bank employees), and media (i.e. newspapers, television, and internet sites). In addition, the survey includes questions regarding additional demographic and socioeconomic information, such as marital and family status, education, employment, and housing status. Of the returned surveys, 13,525 were completely answered. We excluded surveys answered by respondents that stated they were clients in more than one bank. The reason for this was to obtain a fair approximation of the respondent's total financial wealth and proportion invested in stocks. The data do not allow us to identify the amount invested through other banks. It is important to note that in Sweden a vast majority makes investments (i.e. in stocks) through banks. Furthermore, in Sweden, there are very few independent financial advisors, hence most financial advice are received in interactions with banks. Financial wealth is operationalized as the total amount invested through the Bank, i.e., in savings accounts (deposits), mutual funds, and stocks. We include only respondents with positive deposits. The final sample size for which data were available for all variables amounts to 6,871 . See Table 1 for summary statistics. 
We acknowledge that the response rate is relatively low, and that the sample used is a convenience sample. The response rate is, however, in line with similar studies (Kramer, 2016; Lusardi et al., 2011). Comparing the survey data with the register data and the average Swedish population, ${ }^{\mathrm{e}}$ the sample represents the Swedish population, except that individuals responding to the survey are older, wealthier, and better educated. The average age in the sample is 54.6 years (std. dev. 16.9 years), which is higher than the bank register data (49.7 years) and the overall average age in Sweden, which is 41.2 years. The average age in Sweden, however, also includes individuals younger than 18 , whereas our sample includes only individuals who are 18 years old or older. The sample financial wealth in 2013 is, on average, SEK 493,906 with a standard deviation of SEK 1,0 M. The survey financial wealth is higher than the average financial wealth for the Swedish population, whose average financial wealth amounts to SEK 305,000 . It is also higher than wealth reported in the bank's register data, where the average wealth is SEK 317,000. Education is measured according to five alternatives, from no finalized education to post-gymnasial education, three years or longer. The most common educational status is gymnasial education (equivalent to upper secondary school). Compared with the national average, this share is lower (29\% compared with 45\%), and the share of postgymnasial education is higher ( $49 \%$ compared with $34 \%$ ). Thus, the sample is better educated than Swedes in general.

In addition to age, wealth, and education, the models also include as controls the variables gender, large city (i.e., Stockholm, Göteborg, and Malmö), income, mortgage, work status, family status, housing, and risk tolerance. The gender variable $($ men $=1$, women $=0)$, has a mean of 0.47 , thus implicating more women than men in the sample. One-fifth of the sample and the overall population - lives in three large cities $(0.21)$. The mean monthly net income after tax averages SEK 17,817 in December 2013. This is in line with the income of the Swedish population, given the age structure of the sample. The average total debt level is SEK 362,036 in December 2013. The work status variable includes six alternatives: working full time or part time, retired, long-term sick leave, student, or unemployed. The most common work status is working full time (47\%). The share of retired persons is higher in the sample than in the population at large, which is as expected, given the age structure of the sample. Family status includes the alternatives of being single, married, or living in a couples relationship, and having or not having children. The most common family status is being

\footnotetext{
e Data on the Swedish population are collected from Statistics Sweden (SCB) www.scb.se.

${ }^{\mathrm{f}}$ This information was reported in 2007, the most recent statistics available from Statistics Sweden.
} 
married or living in a couples relationship with children (43\%). Housing includes four alternatives: rental apartment, tenant-owned apartment, house, or farmhouse. The most common housing status is house ownership. Compared with the housing situation in Sweden at large, the share of rental apartments is lower (21\% compared with $30 \%$ ), and the share living in a single-family home is higher (57\% compared with $43 \%$ ). The share of tenant-owned apartments is in line with the national average. Risk tolerance is captured through the statement "I can accept losing part of my saving if the chance of getting a good return is great". Answers are indicated on a seven-point Likert scale. The average score on risk tolerance is 3.0 (std. dev. 1.7).

\subsection{Measurements of learning channels, financial literacy, and stock market participation}

The extent to which individuals learn from the three channels - private network, financial advisor, and media - is captured by three questions: Learning from one's private network is captured by the question "I learn about economic matters and financial markets primarily from family and friends". Learning from financial advisors is captured by the questions "I learn about economic matters and financial markets primarily from the bank". As previously explained, there are very few independent financial advisors in Sweden, hence professional financial advice are received in interactions with banks. Learning from media is captured by the question "I learn about economic matters and financial markets primarily from media". Media refers to television, printed newspapers online news sites, and websites and not to interaction with friends through social media. Answers are indicated on a seven-point Likert scale ranging from totally disagree (1) to totally agree (7). In Table 2 the distributions of answers across the 7-point Likert scales are reported as percentages.

\section{[Insert Table 2 here]}

Financial literacy in this paper is defined as knowledge about financial concepts, such as inflation and risk diversification (e.g., Anderson, Baker, and Robinson, 2017; Lusardi, 2008). Financial literacy is measured through a quiz including six questions. We developed the questions in accordance with the Swedish context, and, therefore, they differ to some extent from questions used by, e.g., Anderson, Baker, and Robinson (2017) and Lusardi (2008; 2012). In Sweden, a relatively large part of the population owns their own home or apartment (62\% of the population, according to Statistics Sweden). Half of Swedish households have a 
mortgage, and a majority of these mortgages has variable interest rates. The central bank (the Riksbank) has an inflation target, and to understand the relationship between inflation, and nominal and real interest rates is relevant knowledge for Swedish citizens. In Sweden, it is relatively common to save directly in stocks (about $32 \%$ of the population) and in mutual funds ( $80 \%$ of the population), whereas direct bond investments are less common $(8 \%$ of the population; per Swedish Investment Fund Association, 2016). ${ }^{\mathrm{g}}$ To know that mutual funds have different risk levels, and that saving in equity funds is riskier than saving in balanced or fixed-income funds, is therefore highly relevant. Other important concepts include the price/earnings (P/E) ratio and instruments such as equity-linked securities. Structured products have historically been very profitable and marketed by Swedish banks. Gunnarsson and Wahlund (1997) use a similar context-driven approach when measuring financial literacy in Sweden. The exact wording of the questions is reported in Table 3. Responses to these questions are reported in Table 4 (Panel A).

\section{[Insert Table 3 here] \\ [Insert Table 4 here]}

Most respondents answer the fifth question correctly; the percentage of incorrect answers is only $4.6 \%$. Question number 6 has the lowest percentage of correct answers $-11.6 \%$ - and $80.5 \%$ state that they do not know the answer to this question. Note from panel B of Table 4 that only $3.8 \%$ answer all questions correctly, and on average respondents answers 2.0 questions correctly. ${ }^{\mathrm{h}}$

We summarize the information about financial literacy in a financial literacy index and conduct factor analyses to explicitly take into account the differences between "incorrect" and "do not know" answers. ${ }^{i}$ We construct two dummy variables for each of the six questions. The first dummy indicates if the question was answered correctly, while the other dummy variable refers to the "do not know" answers. Hence, we perform a factor analysis on 12 variables. We retain

\footnotetext{
$\mathrm{g}$ This includes only direct private saving and not pension savings managed by the pension system.

$\mathrm{h}$ These results can be compared with results on the advanced financial literary questions presented in Van Rooij, et al (2011) where 5.0\% answered all ten question correctly (mean 5.93).

${ }^{i}$ Xia, Wang, and Li (2014) perceive the respondent as overconfident if she/he does not select "I don't know" but subsequently makes a wrong answer to financial literacy questions. Anderson, Baker, and Robinson (2017) show that people who overestimate their financial literacy are less likely to select "I don't know" but more likely to make a wrong answer. These respondents are also less likely to seek financial advice.
} 
one factor that describes financial literacy (c.f. van Rooij et al. 2011). Factor loadings are presented in Table A1.

Figures 1A and 1B show the percentages distributions across the Likert scales. Figure 1A

(Figure 1B) shows the distributions for individuals with low (high) levels of financial literacy across the Likert scales of learning channels. The figures show that individuals with high levels of financial literacy learn from media to a larger extent than individuals with low levels of financial literacy. Differences in learning from private networks and financial advisors are less distinct between the individuals with high financial literacy and those with low financial literacy.

\section{[Insert Figure 1 here]}

We analyze stock market participation using two outcome variables constructed from the Bank's register data. As previously explained, financial wealth includes the total amount invested through the Bank in deposits, mutual funds, and stocks. Because we only include respondents who have stated that they do not have any other banks, we expect that we achieve a fair approximation of the respondent's total wealth. The first measure is an indicator variable for whether the individual owns stocks directly. We refer to this variable as participation. The second variable is a continuous variable for the share of financial assets held directly in stocks, conditional on participation. We refer to this variable as share. The data do not allow us to identify the character of the individuals' mutual funds, i.e., whether or not the fund investments are in equity funds. In Sweden, 80\% of the population between 18 and 75 years have savings in mutual funds. This is the highest proportion in the world. Possible explanations include the low fees, easy access, and product transparency (Swedish Investment Fund Association, 2016). Hence, in terms of participation cost, the difference between deposits and mutual fund saving is potentially small. We, therefore, argue that our stock market participation variables reflects an active decision by the investor to buy stocks. As shown in Table 1,27\% of the total sample owns stocks as of December 2013. On average, 5.9\% of the individuals' financial wealth is direct ownership in stocks conditional on participation in December 2013.

\subsection{Financial literacy, learning channels, and stock market participation}

Table 5 shows stock market participation according to use of learning channels and levels of financial literacy. Participation is higher among the individuals with higher levels of financial literacy across all three channels. Those who learn from private networks to a high extent show 
lower participation than those who learn from private networks to a low extent. However, those who learn from financial advisors (media) to a high extent show higher participation than those who learn from financial advisors (media) to a low extent.

\section{[Insert Table 5 here]}

From the correlations reported in Table 6, we observe that our key variables--financial literacy, learning from private networks, learning from the bank, and learning from media--are not highly correlated with each other. The highest correlation, 0.375 , is between financial literacy and learning from media. Therefore, financial literacy and the learning variables capture different investor characteristics.

\section{[Insert Table 6 here]}

\section{Empirical analysis}

\subsection{The effect of financial literacy and learning channels on stock market participation}

We use logit models to explain stock market participation from learning channel variables and financial literacy. The dependent variable, stock market participation (Participation), equals one if the individual owns stocks, and zero otherwise. The values of the learning channel variables are the individual's answers on a seven-point Likert scale in the survey described in Section 3.1. The financial literacy variable is defined based on the financial literacy index described in Section 3.1. It equals one if the individual's value of financial literacy index is above the sample median, and zero otherwise.

We use the latent variable $S t o c k_{i}^{*}$ to determine stock market participation:

If Stock $_{i}^{*} \geq 0$, Participation $=1$.

If Stock $k_{i}^{*}<0$, Participation $=0$.

We estimate the following latent variable model:

Stock $_{i}^{*}=\alpha+\beta$ Private network $_{i}+\gamma$ Financial advisor $_{i}+\theta$ Media $_{i}+$

$\lambda$ Financial literacy $_{i}+\sum_{k} a_{k}^{Z} Z_{k i}+\varepsilon_{i}$,

where $Z_{k i}$ is control variable $k$ for individual $i$, and $\varepsilon_{i}$ is an error term following the standard logistic distribution. 
To study of the moderating effects of financial literacy on the relation between the learning channels and participation, we estimate

$$
\begin{aligned}
& \text { Stock }_{i}^{*}=\alpha+\beta_{1} \text { Private network }_{i} \times \text { Financial literacy }_{i}+ \\
& \gamma_{1} \text { Financial advisor } \times \text { Financial literacy }_{i}+\theta_{1} \text { Media }_{i} \times \\
& \text { Financial literacy }_{i}+\beta_{0} \text { Private network }_{i}+\gamma_{0} \text { Financial advisor }_{i}+ \\
& \theta_{0} \text { Media }_{i}+\lambda \text { Financial literacy }_{i}+\sum_{k} a_{k}^{Z} Z_{k i}+\varepsilon_{i} \text {. }
\end{aligned}
$$

The results for equation (1) and its variations are reported in Table 7. First, we examine the relationship between financial literacy and stock market participation (see column (1)) in the absence of considering learning channels. Consistent with the literature (e.g., with Van Rooij, et al. (2011) and Balloch, Nicolae, and Philip, (2015)), we find that financial literacy is positively associated with stock market participation, as the coefficient for financial literacy in column (1) is positive and statistically significant at $1 \%$. Then, in columns (2) to (4), we examine how every learning channel is respectively associated with stock market participation while not controlling for financial literacy. The variable media is the only learning channel that increases with the likelihood of participating in the stock market. Its coefficient is positive and statistically significant at $1 \%$. In contrast to media, private network and financial advisor have insignificant coefficients. When we consider all the learning channels as explanatory variables (see column (5)), our finding regarding their relationships with participation remains: the coefficient for media is statistically significant while the coefficients for private network and financial advisor stay insignificant. Finally, we use all the learning channel variables to explain participation while controlling for financial literacy. The result is shown in column (6). Comparing column (6) to column (5), we find that the coefficient of media becomes less statistically significant. This can be explained by the fact that financial literacy and media are positively correlated (see Table 6). Nevertheless, the coefficient of media remains positive and statistically significant (at 5\%), indicating that the roles of financial literacy and media for stock market participation are not exchangeable.

\section{[Insert Table 7 here]}

The result in column (6) implies that individuals that score the lowest on media have $20 \%$ probability of participating in the stock market on average, compared to $31 \%$ average probability for those with the highest score on media. Moreover, individuals with low financial literacy have $20 \%$ probability of participating in the stock market on average, compared to $35 \%$ for those with high financial literacy. These remarkable gaps in the probability of stock market 
participation indicate that media and financial literacy are relevant for participation, given that the participation ratio in our sample is about $27 \%$ (see Table 1).

Our results from Table 7 regarding the relationship between learning channels and stock market participation are consistent with the positive effects of access to financial media on stock market participation documented by Liang and Guo (2015). We also echo Balloch, Nicolae, and Philip (2015), who find that social interaction does not matter for participation when financial literacy is controlled for. However, we do not support the finding of Georgarakos and Inderst (2014) about the positive impact of professional financial advice on stock market participation. When comparing our results with findings in the existing literature on stock market participation, it is important to note the difference between our learning channel variables and similar variables used in the existing literature. While the variables in the literature (e.g., Balloch, Nicolae, and Philip, 2015; Hong, Kubik, and Stein, 2004; Georgarakos and Inderst, 2014; Hu et al., 2020; Liang and Guo, 2015) measure the availability of certain channels, i.e., access to financial media and social network, etc., our channel variables capture individuals' strength of learning from the channels. Therefore, our analysis may directly indicate informational effects (or lack thereof) of different learning channels on participation. The striking contrast between the roles of learning channels may arise because different channels provide financial and economic information of different scope and depth.

With regard to the controlled socioeconomic and demographic variables, we find that wealth, debt, risk tolerance, and education are important drivers for participation. Men are more likely to participate than women are, people who are single without children are more likely to participate than people with other types of family status, and people who own their homes (tenant-owned apartment or single family home) are more likely to participate than people living in rental housing.

Next, using equation (2), we analyze whether the relationships between learning channels and stock market participation are reinforced or weakened by financial literacy. Results are presented in Table 8. In columns (1) and (2), financial literacy is interacted with private network and financial advisor, respectively. The interaction terms of financial literacy with private network and financial advisors are insignificant, indicating no moderating effect from financial literacy on the relationship between learning from one's private network or financial advisors and participation. In column (3), we interact financial literacy with media. The coefficients of financial literacy and media are insignificant, while the coefficient for the interaction term of media and financial literacy is positive and statistically significant at $5 \%$. 
As the coefficient of media in column (3) is associated with the partial effect of media when financial literacy equals zero, its insignificance indicates that the likelihood of participating in the stock market does not increase with media if one has low financial literacy. Likewise, the insignificance of the coefficient for financial literacy indicates that the financial literacy variable is not associated with a higher likelihood of participation if one learns through media to the lowest extent. The significance of the interaction term suggests that financial literacy is a necessary condition for media, showing a positive partial effect on stock market participation and vice versa. These results regarding the joint importance of financial literacy and media remain when we include the interactions terms of financial literacy with the other learning channels (in column (4)).

\section{[Insert Table 8 here]}

To visualize the moderating effect of financial literacy on the relationship between media and stock market participation, we illustrate how the interaction of financial literacy and media is associated with the probability of investing in stocks. We group individuals in our sample based on their level of financial literacy and scores on media. For each group, we compute the average participation probability using the estimates in column (4) of Table 8. By doing so, we take into account heterogeneity in all variables across individuals. We see in Figure 2 that, when the score on media increases, the average participation probability of the high financial literacy group increases at a remarkably higher rate than that of the low financial literacy group. As the score on media increases from the lowest end to the highest end, the average participation probability of the high financial literacy group increases from $26 \mathrm{pp}$ to $39 \mathrm{pp}$, while the probability of the low literacy group is increased from $18 \mathrm{pp}$ to $21 \mathrm{pp}$.

\section{[Insert Figure 2 here]}

A possible explanation for our finding that financial literacy reinforces the relationship between learning through media and participation is that media provides wide-ranged information content. It requires pre-knowledge in economic and financial matters for individuals to select, understand, and use relevant information to make investment decisions.

\subsection{The effect of financial literacy, learning channels, and portfolio shares in stocks}


In this section, we explain respondents' portfolios shares in stocks. As portfolio shares in stocks are bounded from below at zero, we estimate tobit models to explain portfolio shares in stocks. We consider the same explanatory variables as in equation (1) and equation (2).

First, we examine how financial literacy and learning channels are associated, respectively, with portfolio shares in stocks. In the variants of tobit regressions presented in columns (1) to (5) Table 9, media and financial literacy are positively associated with portfolio shares in stocks with $1 \%$ statistical significance, and private network and financial advisor have insignificant relationships with portfolio shares in stocks. Analogous to the result regarding participation, the effect of financial literacy (media) becomes smaller when the variable media (financial literacy) is included in the regression (column (6)). However, the roles of these two variables for portfolio shares in stocks are not exchangeable because their coefficients remain strongly statistically significant.

\section{[Insert Table 9 here]}

Furthermore, we examine the economic relevance of media and financial literacy for portfolio shares in stocks. In column (6) of Table 9, where learning channels and financial literacy are all used to explain portfolio shares in stocks, the coefficient for media is 0.01 ; this means that the increase of media by one unit is associated with an increase of 1 percentage point in the portfolio shares invested in stocks for individuals who participate in the stock market. This corresponds to an increase of $6 \mathrm{pp}$ in the portfolio shares in stocks as the score of media increases from the lowest (i.e., one) to the highest (i.e., seven). The coefficient for financial literacy is 0.0466 , indicating that the portfolio shares in stocks increase by $4.66 \mathrm{pp}$ when financial literacy increases from low to high. Given that the sample mean of portfolio shares in stocks conditional on participation is only $5.9 \%$ (see Table 1), the coefficients for media and financial literacy suggest that these two variables have strong economic relevance for investing portfolio shares in stocks,.

Next, we analyze whether financial literacy reinforces or weakens the relationship between learning channels and portfolio shares in stocks. Analogous to our finding regarding participation, the financial literacy is necessary for media to stimulate portfolio shares in stocks, and vice versa. This is suggested by column (3) of Table 10, where the interaction between media and financial literacy is strongly significant and positive while the constituent terms are insignificant. In Figure 3, we plot the partial effect of media on investing portfolio shares in stocks and the $90 \%$ confidence intervals against financial literacy. We can see that the 
estimated partial effect of media on investing portfolio shares in stocks is positively associated with financial literacy. For an individual with high financial literacy, an increase in media by one unit is associated with an increase of about $2 \mathrm{pp}$ in the portfolio shares invested in stocks. This corresponds to an increase of about $12 \mathrm{pp}$ as media increases from the lowest (i.e., one) to the highest (i.e., seven). If financial literacy is lower, the increase of media is not associated with any significant increase in the portfolio shares invested in stocks. The interaction result concerning media support our aforementioned suggestion of promoting simultaneously both financial education and access to financial media and online financial information.

[Insert Table 10 here]

\section{[Insert Figure 3 here]}

Similarly to our finding regarding participation, financial literacy does not moderate the relationship between learning from one's private network or financial advisors and portfolio shares invested in stocks, since the interaction terms of financial literacy with private network and financial advisor in columns (1) and (2) are not statistically significant.

\subsection{Robustness analysis}

We attend to an empirical issue that may lead to overestimation in our results. The issue occurs if our dependent variables, participation and portfolio shares in stocks, are predictors for the explanatory variables, financial literacy, and learning channels. It is plausible that individuals may become more financially literate and pay more attention to financial news in the media as they obtain more experience in the stock market. We mitigate this potential reverse causality issue by using a larger interval between the time of the survey and the time of observing respondents' portfolios. To do so, we construct the dependent variables based on the information of respondents' portfolios observed in March 2016, which is three years after the time of the survey. Comparing the results (available upon request) obtained from using portfolio information in 2016 to the main results obtained from using portfolio information in 2013, we find that the signs and statistical significance of all the coefficients are almost the same. The coefficient of media becomes less significant (10\% for participation and $5 \%$ for portfolio shares) when financial literacy is controlled. The interaction term of financial literacy and media is still significant at $1 \%$ for participation and portfolio shares.

Although our main results concerning media and financial literacy are robust when we use portfolio information observed three years after the time of the survey, we cannot rule out the 
possibility that individuals' investment behaviors are formed earlier in their lives and persist over time. Therefore, we do not claim causality from financial literacy and media to participation and portfolio shares in stocks.

\section{Conclusion}

The literature on household finance has paid increasing attention to factors that affect individuals' investments in stocks. It is generally concluded that knowledge about financial aspects is important to participation in the stock market. The present study investigates the effect of learning through one's private networks, financial advisors, and media, as well as the interactive effect of financial literacy and these learning channels, on stock market participation. We conclude that learning about financial markets and economic matters through media is positively associated with stock market participation, as well as with the share of wealth invested directly in stocks. The direct effects from learning from private networks and financial advisors are insignificant. Investigating interactive effects, we find a positive significant effect of learning from media and financial literacy on stock market participation. We also conclude that the effect of financial literacy becomes insignificant, which indicates that the likelihood of participation does not increase with financial literacy if the individual does not learn from media. Similarly, the sole effect of learning from media has no effect. Our results thus indicate the joint importance of financial literacy and media as a learning channel. We measure direct investments in stocks. Hence, if policymakers want to enhance direct stock market participation, our findings indicate they should promote at the same time both financial education and access to financial media and online financial information. The direct effects of learning from one's private networks and from financial advisors are insignificant. In contrast to learning from media, we find that financial literacy has no interactive effect on the relation between learning from ones' private network or financial advisors and direct stock market participation. Hence, compared with media, advice from family and friends and from financial advisors may be insufficient for individuals to overcome the information barrier of participating in the stock market. 


\section{Figures and Tables}

\section{Figure 1: Learning channels and financial literacy}

Figure 1A shows the distribution of answers on the three survey questions on learning channels for individuals with low financial literacy, and Figure 1B shows the distribution for individuals with high financial literacy.

Figure 1A

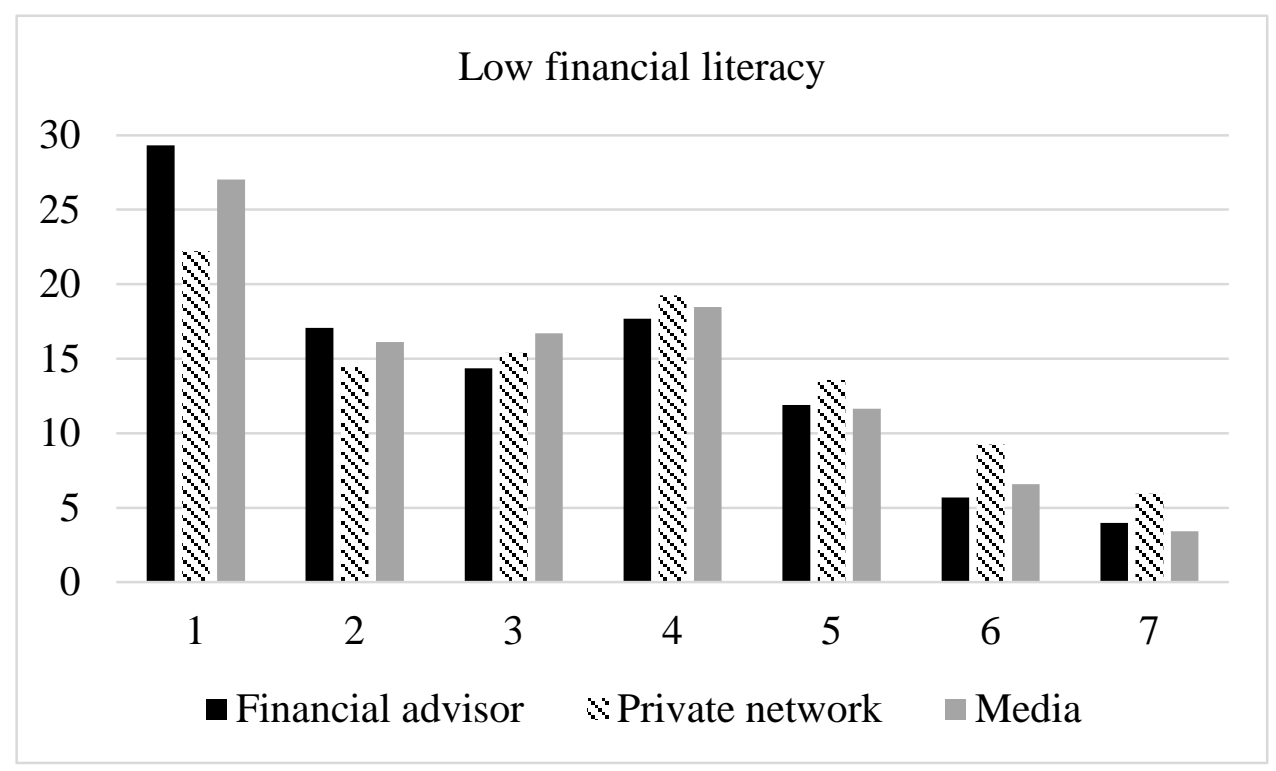

Figure 1B

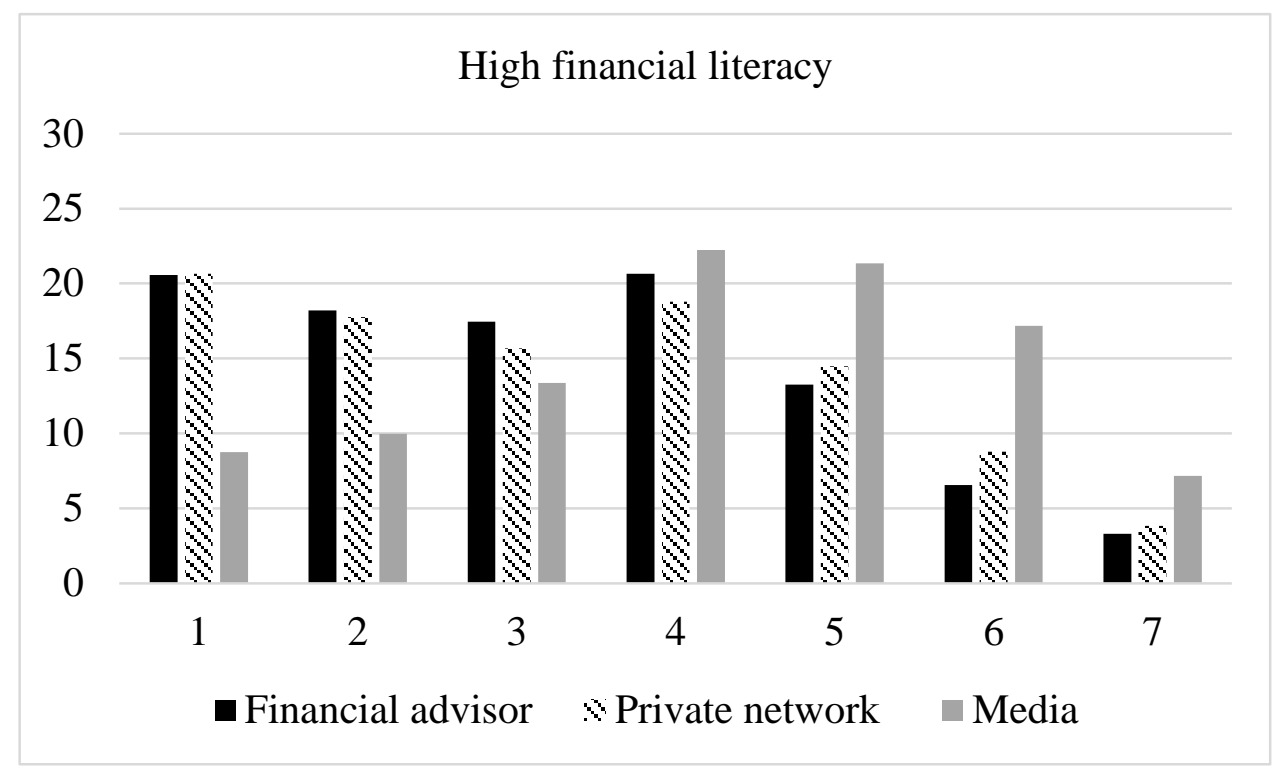


Figure 2. Media, financial literacy, and average implied probability of participating in the stock market

The figure shows the average implied probabilities of participating in the stock market of individuals grouped by the level of learning from media and financial literacy. The probabilities are computed using the estimates in column (4) of Table 8. The dark dots indicate the average probabilities of high financial literacy groups; the grey dots indicate the probabilities of low financial literacy groups.

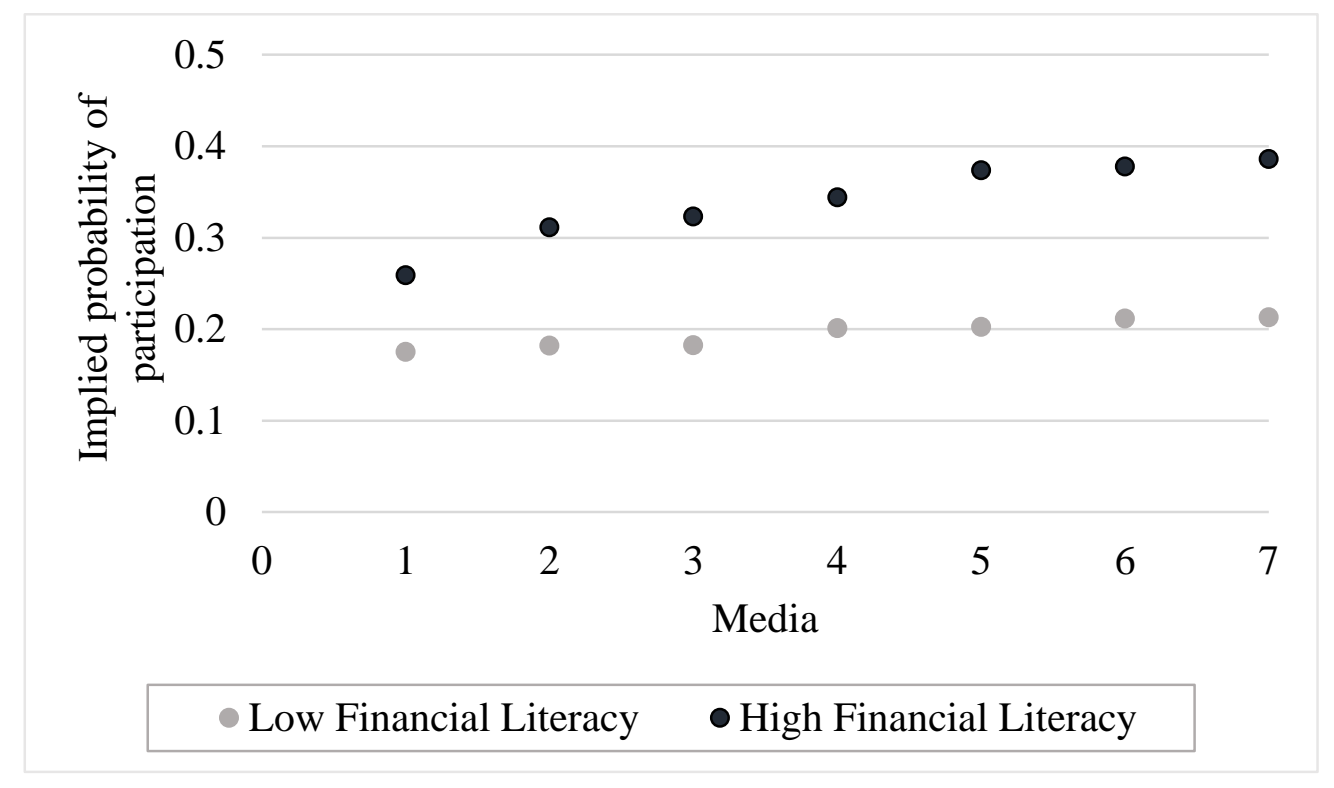




\section{Figure 3. Partial effect of media on portfolio shares in stocks}

The figure shows the partial effect of media on portfolio shares in stocks, given different levels of financial literacy. The partial effect is calculated from the estimates in column (3) in Table 10. The grey dots indicate the marginal effects, and the vertical lines present the $90 \%$ confidence intervals.

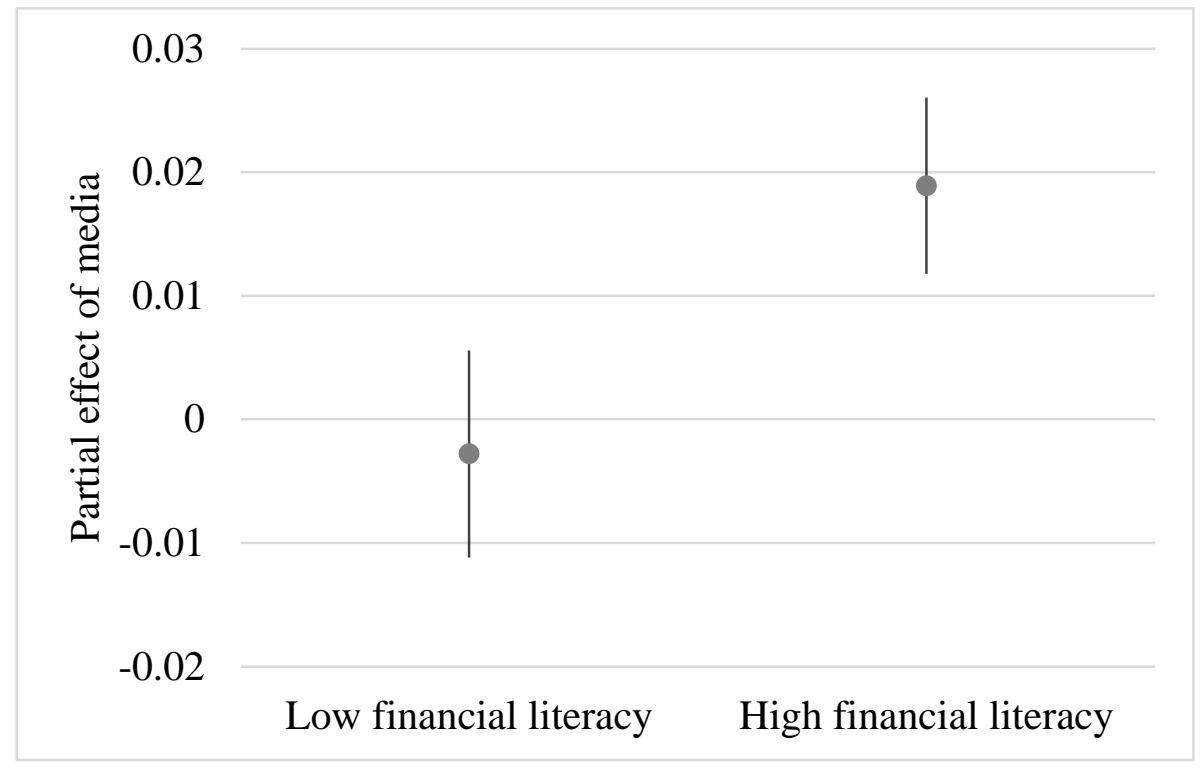




\section{Table 1: Summary statistics}

This table presents summary statistics on the sample of 6,871 survey respondents. Participation, indicates direct stock ownership; share indicates direct stock ownership as a percentage of total wealth. The variables' means, standard deviations, medians, mins, and maxes are reported. For the control variables, we report risk tolerance, income, financial wealth, debt, age, whether the individual lives in a large city, gender, work- and family status, housing situation, and education. Income is the respondent's monthly income net of taxes. Income, wealth, and mortgage are stated in Swedish krona (SEK). Financial wealth is the respondent's total amount invested through the bank in savings accounts, mutual funds, and stocks. Debt is the respondent's total amount of debt (loans and mortgages). On December 31, 2013, SEK 1 was equivalent to USD 0.16. Work status, education, family status, and housing means and the percentage of the respondents that has indicated a certain alternative. Work status ranges from working full time to being far from employment (unemployed). Housing ranges from a low degree of ownership (rental apartment) to a high degree of ownership (single family home). Education ranges from a low level (no finalized education) to a high level (post-gymnasial $\geq 3$ years) of education. Family status ranges from a low degree of relationship involvement (single without children) to a high degree of involvement (couple with children).

\begin{tabular}{|c|c|c|c|c|c|}
\hline Variable & Mean & Std.dev & Median & Min & Max \\
\hline Participation 201312 & 0.273 & 0.446 & 0 & 0 & 1 \\
\hline Participation 201603 & 0.256 & 0.436 & 0 & 0 & 1 \\
\hline Share $201312^{*}$ & 0.059 & 0.149 & 0 & 0 & 1 \\
\hline Share $201603^{*}$ & 0.057 & 0.152 & 0 & 0 & 1 \\
\hline Private network & 3.345 & 1.799 & 3 & 0 & 7 \\
\hline Financial advisor & 3.099 & 1.730 & 3 & 0 & 7 \\
\hline Media & 3.623 & 1.802 & 4 & 0 & 7 \\
\hline Financial literacy & 0.508 & 0.500 & 1 & 0 & 1 \\
\hline Risk tolerance & 3.027 & 1.772 & 3 & 1 & 7 \\
\hline Income_201312 & 17,817 & 12,118 & 16,573 & 0 & 208,000 \\
\hline Income_201603 & 17,705 & 13,580 & 15,696 & 0 & 428,779 \\
\hline Financial wealth_201312 & 493,906 & $1,002,044$ & 223,127 & 1 & $29,1 \mathrm{M}$ \\
\hline Financial wealth_201603 & 563,706 & $1,212,589$ & 259,373 & 0 & $43,5 \mathrm{M}$ \\
\hline Debt_201312 & 362,036 & 916,906 & 0 & 0 & $50 \mathrm{M}$ \\
\hline Debt_201603 & 382,275 & 990,723 & 0 & 0 & $50 \mathrm{M}$ \\
\hline Age & 54.64 & 16.86 & 57 & 18 & 97 \\
\hline Large city & 0.211 & 0.408 & 0 & 0 & 1 \\
\hline Gender & 0.474 & 0.499 & 0 & 0 & 1 \\
\hline Work status & 5.280 & 1.895 & 6 & 1 & 7 \\
\hline Long-term sick leave & 0.011 & 0.102 & & 0 & 1 \\
\hline Pre-retired & 0.026 & 0.158 & & 0 & 1 \\
\hline Retired & 0.313 & 0.464 & & 0 & 1 \\
\hline Unemployed & 0.029 & 0.169 & & 0 & 1 \\
\hline Student & 0.038 & 0.191 & & 0 & 1 \\
\hline Part-time work & 0.114 & 0.318 & & 0 & 1 \\
\hline Full-time work & 0.470 & 0.499 & & 0 & 1 \\
\hline Family status & 2.974 & 1.211 & 3 & 1 & 5 \\
\hline Single w/o children & 0.228 & 0.420 & & 0 & 1 \\
\hline Single w children & 0.041 & 0.198 & & 0 & 1 \\
\hline Couple w/o children & 0.281 & 0.450 & & 0 & 1 \\
\hline Couple w children & 0.428 & 0.495 & & 0 & 1 \\
\hline Others & 0.021 & 0.144 & & 0 & 1 \\
\hline Housing & 3.322 & 0.868 & 4 & 1 & 4 \\
\hline Secondhand rental apartment & 0.020 & 0.138 & & 0 & 1 \\
\hline Rental apartment & 0.209 & 0.407 & & 0 & 1 \\
\hline Tenant-owned apartment & 0.201 & 0.401 & & 0 & 1 \\
\hline Single-family home & 0.570 & 0.495 & & 0 & 1 \\
\hline Education & 3.465 & 1.286 & 3 & 1 & 5 \\
\hline No finalized education & 0.098 & 0.298 & & 0 & 1 \\
\hline Pre-gymnasial & 0.118 & 0.323 & & 0 & 1 \\
\hline Gymnasial & 0.291 & 0.454 & & 0 & 1 \\
\hline Post-gymnasial education $<3$ yrs & 0.204 & 0.403 & & 0 & 1 \\
\hline Post-gymnasial education $\geq 3$ yrs & 0.288 & 0.453 & & 0 & 1 \\
\hline
\end{tabular}


*Conditional on participation. 


\section{Table 2: Learning channels - distribution across the Likert scales}

Table 2 reports the distribution across the Likert scales as the percentages of responses on each level of learning from private network, financial advisor and media, respectively.

\begin{tabular}{cccc}
\hline \multicolumn{4}{c}{ Percentage of rof each level of the learning channel measures } \\
\hline & Private network & Financial advisor & Media \\
\hline 1 & 21.4 & 24.9 & 17.7 \\
2 & 16.1 & 17.6 & 13.0 \\
3 & 15.5 & 15.9 & 15.0 \\
4 & 19.0 & 19.2 & 20.4 \\
5 & 14.0 & 12.6 & 16.6 \\
6 & 9.0 & 6.1 & 12.0 \\
7 & 4.9 & 3.6 & 5.3 \\
\hline
\end{tabular}

\section{Table 3: Financial literacy questions}

The financial literacy questions, in the same order as posed in the questionnaire.

\section{Question formulation}

(1) How high is the Riksbank's inflation target? (i) $1.0 \%$ (ii) $2.0 \%$ (iii) 3\% (iv )Do not know

(2) If there is a risk that the inflation will exceed the inflation target, what should the Riksbank do? (i) Lower the repo rate (ii) Raise the repo rate (iii) Do nothing (iv) Do not know

(3) If the nominal interest rate is $5 \%$, and the expected inflation is $2 \%$, how high will the real interest rate be (approx.)? (i) $2.5 \%$ (ii) $3.0 \%$, (iii) $7.0 \%$ (iv) Do not know

(4) A savings product where you will receive a guaranteed amount at maturity, and the return follows the equity market, is called: (i) Equity fund (ii)Hedge fund (iii) Equity-linked security (iv) Do not know

(5) Mutual funds have different risk levels; which of these mutual fund types is generally viewed as having the highest risk? (i) Balanced fund (ii) Bond fund (iii) Equity fund (iv) Do not know

(6) The definition of the P/E-ratio is (i) Price per share divided by earnings per share (ii) Price per share divided by own capital per share (iii) Price per share divided by sales per share (iv) Do not know

\section{Table 4: Financial literacy}

Panel A reports the proportion of households providing correct, incorrect, and "do not know" answers to each of the six financial literacy questions. Panel B reports the distribution of the number of correct, incorrect, and "do not know" answers on the six financial literacy questions.

\begin{tabular}{|c|c|c|c|c|c|c|c|c|}
\hline \multicolumn{9}{|c|}{ Panel A: Percentage of correct, and incorrect and do not know answers $(\mathrm{N}=6,871)$} \\
\hline & Q1 & Q2 & Q3 & Q4 & Q5 & Q6 & & \\
\hline Correct & 30.1 & 33.2 & 27.2 & 26.9 & 69.1 & 11.6 & & \\
\hline Incorrect & 9.9 & 19 & 8.5 & 11.4 & 4.6 & 7.9 & & \\
\hline Do not know & 60 & 47.8 & 64.3 & 61.7 & 26.3 & 80.5 & & \\
\hline \multicolumn{9}{|c|}{$\begin{array}{l}\text { Panel B: Distribution of number of correct, and incorrect and do not know answers (out of six } \\
\text { questions) }(\mathrm{N}=6,871)\end{array}$} \\
\hline & None & 1 & 2 & 3 & 4 & 5 & All & Mean \\
\hline Correct & 22.5 & 25.7 & 17.3 & 14.2 & 10.0 & 6.6 & 3.8 & 2.0 \\
\hline Incorrect & 59.6 & 25.5 & 10.2 & 3.6 & 0.9 & 0.2 & 0 & 0.6 \\
\hline Do not know & 10.9 & 10.7 & 13.1 & 13.6 & 13.8 & 19.4 & 18.4 & 3.4 \\
\hline
\end{tabular}




\section{Table 5: Stock market participation, learning channels, and financial literacy}

This table shows percentage participation in each group. Groups are defined according to levels of learning from private network, financial advisor and media and levels of financial literacy. High financial literacy is defined as a financial literacy index at, or above, the sample median (1). High private network, high financial advisor, and high media are defined as a score at, or above, the median. The median scores for private network, financial advisor are 3,4 , and 4 , respectively.

\begin{tabular}{lllllll} 
& $\begin{array}{l}\text { Low } \\
\text { private } \\
\text { network }\end{array}$ & $\begin{array}{l}\text { High } \\
\text { private } \\
\text { network }\end{array}$ & $\begin{array}{l}\text { Low } \\
\text { financial } \\
\text { advisor }\end{array}$ & $\begin{array}{l}\text { High } \\
\text { financial } \\
\text { advisor }\end{array}$ & $\begin{array}{l}\text { Low } \\
\text { media }\end{array}$ & $\begin{array}{l}\text { High } \\
\text { media }\end{array}$ \\
\hline Low financial literacy & 23.0 & 17.9 & 14.1 & 24.7 & 19.4 & 20.3 \\
High financial literacy & 40.4 & 31.5 & 28.4 & 39.0 & 31.3 & 36.6 \\
\hline
\end{tabular}




\section{Table 6: Correlation matrix}

This table reports the Pearson correlations for the main variables in the sample. ${ }^{*}$ indicates significance at $1 \%$.

\begin{tabular}{|c|c|c|c|c|c|c|}
\hline & 1 & 2 & 3 & 4 & 5 & 7 \\
\hline 1. Participation & 1.000 & & & & & \\
\hline 2. Share & $0.640^{*}$ & 1.000 & & & & \\
\hline 3. Private network & $-0.078^{*}$ & $-0.051^{*}$ & 1.000 & & & \\
\hline 4. Bank & $0.150^{*}$ & $0.060^{*}$ & $0.068^{*}$ & 1.000 & & \\
\hline 5. Media & $0.094^{*}$ & $0.098^{*}$ & $0.136^{*}$ & $0.073^{*}$ & 1.000 & \\
\hline 7. Financial literacy & $0.167^{*}$ & $0.151^{*}$ & -0.024 & $0.064^{*}$ & $0.312^{*}$ & 1.000 \\
\hline
\end{tabular}


Table 7: Financial literacy, learning channels, and stock market participation

This table shows the estimates of the logit regression (equations (1)) of stock market participation (participation) on learning channel variables, financial literacy, and a set of controls. Note: Standard errors are reported in parentheses; ${ }^{* * *} \mathrm{p}<0.01,{ }^{* *} \mathrm{p}<0.05,{ }^{*} \mathrm{p}<0.1$.

\begin{tabular}{|c|c|c|c|c|c|c|}
\hline $\begin{array}{l}\text { VARIABLES: } \\
\text { Participation }\end{array}$ & (1) & (2) & (3) & (4) & (5) & (6) \\
\hline Private network & & $\begin{array}{l}-0.0103 \\
(0.0193)\end{array}$ & & & $\begin{array}{l}-0.0169 \\
(0.0195)\end{array}$ & $\begin{array}{l}-0.0166 \\
(0.0195)\end{array}$ \\
\hline Financial advisor & & & $\begin{array}{l}0.0138 \\
(0.0193)\end{array}$ & & $\begin{array}{l}0.0153 \\
(0.0194)\end{array}$ & $\begin{array}{l}0.0160 \\
(0.0194)\end{array}$ \\
\hline Media & & & & $\begin{array}{l}0.0514^{* * *} \\
(0.0198)\end{array}$ & $\begin{array}{l}0.0535^{* * *} \\
(0.0200)\end{array}$ & $\begin{array}{l}0.0421^{* *} \\
(0.0204)\end{array}$ \\
\hline Financial literacy & $\begin{array}{l}0.2255^{* * * *} \\
(0.0705)\end{array}$ & & & & & $\begin{array}{l}0.1966^{* * *} \\
(0.0721)\end{array}$ \\
\hline Ln(income+1) & $\begin{array}{l}0.0029 \\
(0.0137)\end{array}$ & $\begin{array}{l}0.0030 \\
(0.0137)\end{array}$ & $\begin{array}{l}0.0027 \\
(0.0137)\end{array}$ & $\begin{array}{l}0.0026 \\
(0.0137)\end{array}$ & $\begin{array}{l}0.0023 \\
(0.0137)\end{array}$ & $\begin{array}{l}0.0023 \\
(0.0137)\end{array}$ \\
\hline $\operatorname{Ln}($ wealth +1$)$ & $\begin{array}{l}0.9655^{* * *} \\
(0.0347)\end{array}$ & $\begin{array}{l}0.9749^{* * *} \\
(0.0346)\end{array}$ & $\begin{array}{l}0.9708^{* * *} \\
(0.0352)\end{array}$ & $\begin{array}{l}0.9731^{* * *} \\
(0.0346)\end{array}$ & $\begin{array}{l}0.9667^{* * *} \\
(0.0352)\end{array}$ & $\begin{array}{l}0.9583^{* * *} \\
(0.0353)\end{array}$ \\
\hline $\operatorname{Ln}($ debt+1) & $\begin{array}{l}0.0148^{* * *} \\
(0.0058)\end{array}$ & $\begin{array}{l}0.0157^{* * * *} \\
(0.0058)\end{array}$ & $\begin{array}{l}0.0156^{* * *} \\
(0.0058)\end{array}$ & $\begin{array}{l}0.0150^{* * * *} \\
(0.0058)\end{array}$ & $\begin{array}{l}0.0146^{* *} \\
(0.0058)\end{array}$ & $\begin{array}{l}0.0138^{* * *} \\
(0.0058)\end{array}$ \\
\hline Risk tolerance & $\begin{array}{l}0.1169^{* * * *} \\
(0.0188)\end{array}$ & $\begin{array}{l}0.1261^{* * * *} \\
(0.0187)\end{array}$ & $\begin{array}{l}0.1232^{* * * *} \\
(0.0188)\end{array}$ & $\begin{array}{l}0.1146^{* * * *} \\
(0.0191)\end{array}$ & $\begin{array}{l}0.1138^{* * * *} \\
(0.0193)\end{array}$ & $\begin{array}{l}0.1088^{* * *} \\
(0.0194)\end{array}$ \\
\hline Age & $\begin{array}{l}0.0062 \\
(0.0155)\end{array}$ & $\begin{array}{l}0.0072 \\
(0.0156)\end{array}$ & $\begin{array}{l}0.0079 \\
(0.0155)\end{array}$ & $\begin{array}{l}0.0074 \\
(0.0155)\end{array}$ & $\begin{array}{l}0.0059 \\
(0.0156)\end{array}$ & $\begin{array}{l}0.0045 \\
(0.0156)\end{array}$ \\
\hline $\mathrm{Age}^{2}$ & $\begin{array}{l}0.0000 \\
(0.0001)\end{array}$ & $\begin{array}{l}0.0000 \\
(0.0001)\end{array}$ & $\begin{array}{l}0.0000 \\
(0.0001)\end{array}$ & $\begin{array}{l}0.0000 \\
(0.0001)\end{array}$ & $\begin{array}{l}0.0001 \\
(0.0001)\end{array}$ & $\begin{array}{l}0.0001 \\
(0.0001)\end{array}$ \\
\hline Large city & $\begin{array}{l}-0.0513 \\
(0.0476)\end{array}$ & $\begin{array}{l}-0.0486 \\
(0.0475)\end{array}$ & $\begin{array}{l}-0.0488 \\
(0.0475)\end{array}$ & $\begin{array}{l}-0.0546 \\
(0.0477)\end{array}$ & $\begin{array}{l}-0.0541 \\
(0.0477)\end{array}$ & $\begin{array}{l}-0.0548 \\
(0.0477)\end{array}$ \\
\hline Gender & $\begin{array}{l}0.1590^{* * *} \\
(0.0727)\end{array}$ & $\begin{array}{l}0.2093^{* * * *} \\
(0.0711)\end{array}$ & $\begin{array}{l}0.2197^{* * * *} \\
(0.0710)\end{array}$ & $\begin{array}{l}0.1816^{* *} \\
(0.0717)\end{array}$ & $\begin{array}{l}0.1786^{* *} \\
(0.0728)\end{array}$ & $\begin{array}{l}0.1381^{*} \\
(0.0744)\end{array}$ \\
\hline Work status & & & & & & \\
\hline Pre-retired & $\begin{array}{l}0.2569 \\
(0.4316)\end{array}$ & $\begin{array}{l}0.2840 \\
(0.4316)\end{array}$ & $\begin{array}{l}0.2864 \\
(0.4323)\end{array}$ & $\begin{array}{l}0.2350 \\
(0.4322)\end{array}$ & $\begin{array}{l}0.2458 \\
(0.4323)\end{array}$ & $\begin{array}{l}0.2363 \\
(0.4320)\end{array}$ \\
\hline
\end{tabular}




\begin{tabular}{|c|c|c|c|c|c|c|}
\hline Retired & $\begin{array}{l}0.0103 \\
(0.3906)\end{array}$ & $\begin{array}{l}0.0488 \\
(0.3905)\end{array}$ & $\begin{array}{l}0.0501 \\
(0.3913)\end{array}$ & $\begin{array}{l}0.0130 \\
(0.3907)\end{array}$ & $\begin{array}{l}0.0174 \\
(0.3907)\end{array}$ & $\begin{array}{l}-0.0067 \\
(0.3905)\end{array}$ \\
\hline Unemployed & $\begin{array}{l}-0.2886 \\
(0.4666)\end{array}$ & $\begin{array}{l}-0.2546 \\
(0.4659)\end{array}$ & $\begin{array}{l}-0.2481 \\
(0.4667)\end{array}$ & $\begin{array}{l}-0.2783 \\
(0.4662)\end{array}$ & $\begin{array}{l}-0.2752 \\
(0.4663)\end{array}$ & $\begin{array}{l}-0.2991 \\
(0.4666)\end{array}$ \\
\hline Student & $\begin{array}{l}-0.0498 \\
(0.4709)\end{array}$ & $\begin{array}{l}0.0067 \\
(0.4703)\end{array}$ & $\begin{array}{l}0.0075 \\
(0.4709)\end{array}$ & $\begin{array}{l}-0.0339 \\
(0.4708)\end{array}$ & $\begin{array}{l}-0.0293 \\
(0.4709)\end{array}$ & $\begin{array}{l}-0.0676 \\
(0.4711)\end{array}$ \\
\hline Part-time & $\begin{array}{l}-0.2757 \\
(0.3950)\end{array}$ & $\begin{array}{l}-0.2413 \\
(0.3949)\end{array}$ & $\begin{array}{l}-0.2413 \\
(0.3957)\end{array}$ & $\begin{array}{l}-0.2765 \\
(0.3951)\end{array}$ & $\begin{array}{l}-0.2710 \\
(0.3951)\end{array}$ & $\begin{array}{l}-0.2911 \\
(0.3949)\end{array}$ \\
\hline Full-time & $\begin{array}{l}-0.3280 \\
(0.3849)\end{array}$ & $\begin{array}{l}-0.2962 \\
(0.3849)\end{array}$ & $\begin{array}{l}-0.2928 \\
(0.3857)\end{array}$ & $\begin{array}{l}-0.3248 \\
(0.3850)\end{array}$ & $\begin{array}{l}-0.3165 \\
(0.3850)\end{array}$ & $\begin{array}{l}-0.3358 \\
(0.3848)\end{array}$ \\
\hline \multicolumn{7}{|l|}{ Education } \\
\hline Below high school & $\begin{array}{l}0.2639^{*} \\
(0.1380)\end{array}$ & $\begin{array}{l}0.2984^{* *} \\
(0.1375)\end{array}$ & $\begin{array}{l}0.2962^{* *} \\
(0.1376)\end{array}$ & $\begin{array}{l}0.2699^{*} \\
(0.1380)\end{array}$ & $\begin{array}{l}0.2690^{*} \\
(0.1381)\end{array}$ & $\begin{array}{l}0.2458^{*} \\
(0.1385)\end{array}$ \\
\hline High school & $\begin{array}{l}0.3154^{* *} \\
(0.1298)\end{array}$ & $\begin{array}{l}0.3646^{* * * *} \\
(0.1290)\end{array}$ & $\begin{array}{l}0.3609^{* * * *} \\
(0.1290)\end{array}$ & $\begin{array}{l}0.3262^{* *} \\
(0.1297)\end{array}$ & $\begin{array}{l}0.3264^{* *} \\
(0.1298)\end{array}$ & $\begin{array}{l}0.2933^{* *} \\
(0.1304)\end{array}$ \\
\hline $\begin{array}{l}<3 \text { years education after } \\
\text { high school }\end{array}$ & $\begin{array}{l}0.3945^{* * *} \\
(0.1326)\end{array}$ & $\begin{array}{l}0.4510^{* * *} \\
(0.1315)\end{array}$ & $\begin{array}{l}0.4488^{* * *} \\
(0.1315)\end{array}$ & $\begin{array}{l}0.4078^{* * *} \\
(0.1325)\end{array}$ & $\begin{array}{l}0.4081^{* * *} \\
(0.1325)\end{array}$ & $\begin{array}{l}0.3694^{* * *} \\
(0.1333)\end{array}$ \\
\hline $\begin{array}{l}\geq 3 \text { years education after } \\
\text { high school }\end{array}$ & $\begin{array}{l}0.3229^{* *} \\
(0.1303)\end{array}$ & $\begin{array}{l}0.3953^{* * *} \\
(0.1285)\end{array}$ & $\begin{array}{l}0.3941^{* * *} \\
(0.1285)\end{array}$ & $\begin{array}{l}0.3479^{* * *} \\
(0.1296)\end{array}$ & $\begin{array}{l}0.3500^{* * *} \\
(0.1297)\end{array}$ & $\begin{array}{l}0.2985^{* *} \\
(0.1311)\end{array}$ \\
\hline \multicolumn{7}{|l|}{ Family status } \\
\hline Single with children & $\begin{array}{l}-0.5866^{* * *} \\
(0.2027)\end{array}$ & $\begin{array}{l}-0.5837^{* * *} \\
(0.2026)\end{array}$ & $\begin{array}{l}-0.5852^{* * *} \\
(0.2025)\end{array}$ & $\begin{array}{l}-0.5778^{* * *} \\
(0.2028)\end{array}$ & $\begin{array}{l}-0.5726^{* * *} \\
(0.2028)\end{array}$ & $\begin{array}{l}-0.5752^{* * *} \\
(0.2028)\end{array}$ \\
\hline $\begin{array}{l}\text { Married/cohabiting } \\
\text { without children }\end{array}$ & $\begin{array}{l}-0.2477^{* * *} \\
(0.0933)\end{array}$ & $\begin{array}{l}-0.2308^{* *} \\
(0.0932)\end{array}$ & $\begin{array}{l}-0.2348^{* *} \\
(0.0931)\end{array}$ & $\begin{array}{l}-0.2466^{* * *} \\
(0.0933)\end{array}$ & $\begin{array}{l}-0.2452^{* * *} \\
(0.0934)\end{array}$ & $\begin{array}{l}-0.2550^{* * * *} \\
(0.0936)\end{array}$ \\
\hline $\begin{array}{l}\text { Married/cohabiting with } \\
\text { children }\end{array}$ & $\begin{array}{l}-0.4144^{* * *} \\
(0.0951)\end{array}$ & $\begin{array}{l}-0.3998^{* * *} \\
(0.0949)\end{array}$ & $\begin{array}{l}-0.4028^{* * *} \\
(0.0948)\end{array}$ & $\begin{array}{l}-0.4111^{* * *} \\
(0.0950)\end{array}$ & $\begin{array}{l}-0.4091^{* * *} \\
(0.0951)\end{array}$ & $\begin{array}{l}-0.4180^{\text {**** }} \\
(0.0953)\end{array}$ \\
\hline Other & $\begin{array}{l}-0.6256^{*} \\
(0.3779)\end{array}$ & $\begin{array}{l}-0.6041 \\
(0.3792)\end{array}$ & $\begin{array}{l}-0.6013 \\
(0.3788)\end{array}$ & $\begin{array}{l}-0.6171 \\
(0.3812)\end{array}$ & $\begin{array}{l}-0.6176 \\
(0.3814)\end{array}$ & $\begin{array}{l}-0.6332^{*} \\
(0.3800)\end{array}$ \\
\hline \multicolumn{7}{|l|}{ Housing } \\
\hline Rental & $\begin{array}{l}0.5794 \\
(0.4109)\end{array}$ & $\begin{array}{l}0.6117 \\
(0.4138)\end{array}$ & $\begin{array}{l}0.6144 \\
(0.4149)\end{array}$ & $\begin{array}{l}0.6276 \\
(0.4158)\end{array}$ & $\begin{array}{l}0.6280 \\
(0.4163)\end{array}$ & $\begin{array}{l}0.5953 \\
(0.4131)\end{array}$ \\
\hline Tenant-owned apartment & $0.7876^{*}$ & $0.8322^{* *}$ & $0.8346^{* *}$ & $0.8365^{* *}$ & $0.8372^{* *}$ & $0.7966^{*}$ \\
\hline
\end{tabular}




\begin{tabular}{lllllll} 
& $(0.4106)$ & $(0.4134)$ & $(0.4145)$ & $(0.4153)$ & $(0.4158)$ & $(0.4128)$ \\
Single family home & $0.8573^{* *}$ & $0.8991^{* *}$ & $0.9000^{* *}$ & $0.9083^{* *}$ & $0.9088^{* *}$ & $0.8699^{* *}$ \\
& $(0.4106)$ & $(0.4133)$ & $(0.4144)$ & $(0.4153)$ & $(0.4158)$ & $(0.4128)$ \\
Constant & $-14.9522^{* * *}$ & $-15.1426^{* * *}$ & $-15.1903^{* * *}$ & $-15.2390^{* * *}$ & $-15.1101^{* * *}$ & $-14.8808^{* * *}$ \\
& $(0.7692)$ & $(0.7779)$ & $(0.7693)$ & $(0.7697)$ & $(0.7800)$ & $(0.7812)$ \\
& & & & & \\
Pseudo R2 & 0.2631 & 0.2619 & 0.2619 & 0.2677 & 0.2628 & 0.2638 \\
Log likelihood & -2970.44 & -2975.42 & -2975.31 & -2972.21 & -2971.55 & -2967.83 \\
Observations & 6871 & 6871 & 6871 & 6871 & 6871 & 6871 \\
\hline
\end{tabular}




\section{Table 8: Interaction of learning channels with financial literacy and stock market participation}

This table shows the estimates of the logit regression (equations (2)) of stock market participation on learning channel variables, financial literacy, and a set of controls. Note: Standard errors are reported in parentheses; ${ }^{* * *}$ $\mathrm{p}<0.01,{ }^{* *} \mathrm{p}<0.05,{ }^{*} \mathrm{p}<0.1$.

\begin{tabular}{lllll}
\hline Dependent variable: Participation & $(1)$ & $(2)$ & $(3)$ & $(4)$ \\
Private network & -0.0021 & -0.0166 & -0.0114 & 0.0138 \\
& $(0.0290)$ & $(0.0195)$ & $(0.0196)$ & $(0.0294)$ \\
Financial advisor & 0.0160 & 0.0109 & 0.0210 & 0.0172 \\
& $(0.0194)$ & $(0.0285)$ & $(0.0195)$ & $(0.0285)$ \\
Media & $0.0409^{* *}$ & $0.0425^{* *}$ & -0.0184 & -0.0243 \\
& $(0.0205)$ & $(0.0205)$ & $(0.0309)$ & $(0.0315)$ \\
Private network $\times$ financial literacy & -0.0252 & & & -0.0433 \\
& $(0.0373)$ & & & $(0.0378)$ \\
Financial advisor $\times$ financial literacy & & 0.0094 & & $(0.0379)$ \\
Media $\times$ financial literacy & & $(0.0379)$ & & $0.1115^{* * *}$ \\
Financial literacy & & & $0.1041^{* * *}$ & $(0.0403)$ \\
& & & $(0.0397)$ & -0.0850 \\
Controls & $0.2804^{*}$ & 0.1643 & -0.1765 & $(0.2246)$ \\
Pseudo R2 & $(0.1435)$ & $(0.1489)$ & $(0.1594)$ & Yes \\
Log likelihood & & & & Yes \\
Observations & Yes & Yes & & 0.2648 \\
\hline
\end{tabular}


Table 9: Learning channels, financial literacy, and portfolio shares in stocks

This table shows the estimates of the tobit regression of portfolio share in stocks on learning channel variables, financial literacy, and a set of controls. The dependent variable, portfolio share in stocks, is bounded at zero from below. Note: Standard errors are reported in parentheses; ${ }^{* * *} \mathrm{p}<0.01,{ }^{* * *} \mathrm{p}<0.05,{ }^{*} \mathrm{p}<0.1$.

\begin{tabular}{|c|c|c|c|c|c|c|}
\hline $\begin{array}{l}\text { VARIABLES: } \\
\text { Participation }\end{array}$ & (1) & $(2)$ & (3) & (4) & $(5)$ & $(6)$ \\
\hline Private network & & $\begin{array}{l}0.0010 \\
(0.0032)\end{array}$ & & & $\begin{array}{l}-0.0000 \\
(0.0032)\end{array}$ & $\begin{array}{l}0.0001 \\
(0.0032)\end{array}$ \\
\hline Financial advisor & & & $\begin{array}{l}-0.0035 \\
(0.0032)\end{array}$ & & $\begin{array}{l}-0.0032 \\
(0.0032)\end{array}$ & $\begin{array}{l}-0.0032 \\
(0.0032)\end{array}$ \\
\hline Media & & & & $\begin{array}{l}0.0127^{\text {**** }} \\
(0.0033)\end{array}$ & $\begin{array}{l}0.0127^{* * *} \\
(0.0033)\end{array}$ & $\begin{array}{l}0.0100^{* * *} \\
(0.0034)\end{array}$ \\
\hline Financial literacy & $\begin{array}{l}0.0543^{* * *} \\
(0.0119)\end{array}$ & & & & & $\begin{array}{l}0.0466^{* * *} \\
(0.0121)\end{array}$ \\
\hline $\operatorname{Ln}($ income +1$)$ & $\begin{array}{l}-0.0006 \\
(0.0023)\end{array}$ & $\begin{array}{l}-0.0006 \\
(0.0023)\end{array}$ & $\begin{array}{l}-0.0005 \\
(0.0023)\end{array}$ & $\begin{array}{l}-0.0006 \\
(0.0023)\end{array}$ & $\begin{array}{l}-0.0005 \\
(0.0023)\end{array}$ & $\begin{array}{l}-0.0005 \\
(0.0022)\end{array}$ \\
\hline $\operatorname{Ln}($ wealth +1$)$ & $\begin{array}{l}0.1365^{\text {**** }} \\
(0.0053)\end{array}$ & $\begin{array}{l}0.1392^{* * *} \\
(0.0053)\end{array}$ & $\begin{array}{l}0.1402^{\text {*** }} \\
(0.0054)\end{array}$ & $\begin{array}{l}0.1383^{\text {**** }} \\
(0.0053)\end{array}$ & $\begin{array}{l}0.1392^{* * *} \\
(0.0054)\end{array}$ & $\begin{array}{l}0.1371^{* * *} \\
(0.0054)\end{array}$ \\
\hline $\operatorname{Ln}($ debt +1$)$ & $\begin{array}{l}0.0025^{\text {**** }} \\
(0.0010)\end{array}$ & $\begin{array}{l}0.0027^{* * *} \\
(0.0010)\end{array}$ & $\begin{array}{l}0.0027^{* * *} \\
(0.0010)\end{array}$ & $\begin{array}{l}0.0025^{\text {**** }} \\
(0.0010)\end{array}$ & $\begin{array}{l}0.0025^{* * *} \\
(0.0010)\end{array}$ & $\begin{array}{l}0.0024^{* *} \\
(0.0010)\end{array}$ \\
\hline Risk tolerance & $\begin{array}{l}0.0208^{* * * *} \\
(0.0032)\end{array}$ & $\begin{array}{l}0.0228^{* * *} \\
(0.0031)\end{array}$ & $\begin{array}{l}0.0233^{* * * *} \\
(0.0032)\end{array}$ & $\begin{array}{l}0.0201^{\text {**** }} \\
(0.0032)\end{array}$ & $\begin{array}{l}0.0205^{* * *} \\
(0.0032)\end{array}$ & $\begin{array}{l}0.0193^{* * *} \\
(0.0032)\end{array}$ \\
\hline Age & $\begin{array}{l}-0.0006 \\
(0.0025)\end{array}$ & $\begin{array}{l}-0.0001 \\
(0.0026)\end{array}$ & $\begin{array}{l}-0.0002 \\
(0.0025)\end{array}$ & $\begin{array}{l}-0.0003 \\
(0.0025)\end{array}$ & $\begin{array}{l}-0.0003 \\
(0.0026)\end{array}$ & $\begin{array}{l}-0.0006 \\
(0.0025)\end{array}$ \\
\hline $\mathrm{Age}^{2}$ & $\begin{array}{l}0.0000 \\
(0.0000)\end{array}$ & $\begin{array}{l}0.0000 \\
(0.0000)\end{array}$ & $\begin{array}{l}0.0000 \\
(0.0000)\end{array}$ & $\begin{array}{l}0.0000 \\
(0.0000)\end{array}$ & $\begin{array}{l}0.0000 \\
(0.0000)\end{array}$ & $\begin{array}{l}0.0000 \\
(0.0000)\end{array}$ \\
\hline Large city & $\begin{array}{l}-0.0082 \\
(0.0080)\end{array}$ & $\begin{array}{l}-0.0079 \\
(0.0080)\end{array}$ & $\begin{array}{l}-0.0078 \\
(0.0080)\end{array}$ & $\begin{array}{l}-0.0091 \\
(0.0080)\end{array}$ & $\begin{array}{l}-0.0090 \\
(0.0080)\end{array}$ & $\begin{array}{l}-0.0091 \\
(0.0080)\end{array}$ \\
\hline Gender & $\begin{array}{l}0.0390^{* * *} \\
(0.0121)\end{array}$ & $\begin{array}{l}0.0529^{* * *} \\
(0.0119)\end{array}$ & $\begin{array}{l}0.0508^{* * *} \\
(0.0119)\end{array}$ & $\begin{array}{l}0.0443^{\text {*** }} \\
(0.0119)\end{array}$ & $\begin{array}{l}0.0429^{* * *} \\
(0.0121)\end{array}$ & $\begin{array}{l}0.0332^{* * *} \\
(0.0123)\end{array}$ \\
\hline \multicolumn{7}{|l|}{ Work Status } \\
\hline Pre-retired & $\begin{array}{l}-0.0262 \\
(0.0686)\end{array}$ & $\begin{array}{l}-0.0203 \\
(0.0689)\end{array}$ & $\begin{array}{l}-0.0208 \\
(0.0688)\end{array}$ & $\begin{array}{l}-0.0317 \\
(0.0687)\end{array}$ & $\begin{array}{l}-0.0326 \\
(0.0687)\end{array}$ & $\begin{array}{l}-0.0355 \\
(0.0685)\end{array}$ \\
\hline
\end{tabular}




\begin{tabular}{|c|c|c|c|c|c|c|}
\hline Retired & $\begin{array}{l}-0.0672 \\
(0.0616)\end{array}$ & $\begin{array}{l}-0.0589 \\
(0.0619)\end{array}$ & $\begin{array}{l}-0.0591 \\
(0.0617)\end{array}$ & $\begin{array}{l}-0.0671 \\
(0.0617)\end{array}$ & $\begin{array}{l}-0.0674 \\
(0.0616)\end{array}$ & $\begin{array}{l}-0.0730 \\
(0.0614)\end{array}$ \\
\hline Unemployed & $\begin{array}{l}-0.1210 \\
(0.0737)\end{array}$ & $\begin{array}{l}-0.1133 \\
(0.0739)\end{array}$ & $\begin{array}{l}-0.1151 \\
(0.0739)\end{array}$ & $\begin{array}{l}-0.1196 \\
(0.0737)\end{array}$ & $\begin{array}{l}-0.1211 \\
(0.0737)\end{array}$ & $\begin{array}{l}-0.1262^{*} \\
(0.0735)\end{array}$ \\
\hline Student & $\begin{array}{l}-0.0690 \\
(0.0743)\end{array}$ & $\begin{array}{l}-0.0583 \\
(0.0745)\end{array}$ & $\begin{array}{l}-0.0590 \\
(0.0745)\end{array}$ & $\begin{array}{l}-0.0666 \\
(0.0743)\end{array}$ & $\begin{array}{l}-0.0674 \\
(0.0742)\end{array}$ & $\begin{array}{l}-0.0749 \\
(0.0741)\end{array}$ \\
\hline Part-time & $\begin{array}{l}-0.1203^{*} \\
(0.0625)\end{array}$ & $\begin{array}{l}-0.1137^{*} \\
(0.0628)\end{array}$ & $\begin{array}{l}-0.1138^{*} \\
(0.0627)\end{array}$ & $\begin{array}{l}-0.1210^{*} \\
(0.0626)\end{array}$ & $\begin{array}{l}-0.1214^{*} \\
(0.0625)\end{array}$ & $\begin{array}{l}-0.1256^{* *} \\
(0.0624)\end{array}$ \\
\hline Full-time & $\begin{array}{l}-0.1244^{* *} \\
(0.0607)\end{array}$ & $\begin{array}{l}-0.1182^{*} \\
(0.0609)\end{array}$ & $\begin{array}{l}-0.1191^{*} \\
(0.0608)\end{array}$ & $\begin{array}{l}-0.1246^{* *} \\
(0.0607)\end{array}$ & $\begin{array}{l}-0.1257^{* * *} \\
(0.0606)\end{array}$ & $\begin{array}{l}-0.1298^{* *} \\
(0.0605)\end{array}$ \\
\hline \multicolumn{7}{|l|}{ Education } \\
\hline Below high school & $\begin{array}{l}0.0330 \\
(0.0229)\end{array}$ & $\begin{array}{l}0.0416^{*} \\
(0.0229)\end{array}$ & $\begin{array}{l}0.0419^{*} \\
(0.0229)\end{array}$ & $\begin{array}{l}0.0349 \\
(0.0229)\end{array}$ & $\begin{array}{l}0.0352 \\
(0.0229)\end{array}$ & $\begin{array}{l}0.0291 \\
(0.0229)\end{array}$ \\
\hline High school & $\begin{array}{l}0.0442^{* * *} \\
(0.0215)\end{array}$ & $\begin{array}{l}0.0556^{* * * *} \\
(0.0215)\end{array}$ & $\begin{array}{l}0.0562^{* * * *} \\
(0.0215)\end{array}$ & $\begin{array}{l}0.0465^{* *} \\
(0.0216)\end{array}$ & $\begin{array}{l}0.0468^{* *} \\
(0.0216)\end{array}$ & $\begin{array}{l}0.0388^{*} \\
(0.0216)\end{array}$ \\
\hline $\begin{array}{l}<3 \text { years education after } \\
\text { high school }\end{array}$ & $\begin{array}{l}0.0549^{* *} \\
(0.0220)\end{array}$ & $\begin{array}{l}0.0689^{* * *} \\
(0.0219)\end{array}$ & $\begin{array}{l}0.0690^{* * *} \\
(0.0219)\end{array}$ & $\begin{array}{l}0.0586^{* * *} \\
(0.0220)\end{array}$ & $\begin{array}{l}0.0586^{* * *} \\
(0.0220)\end{array}$ & $\begin{array}{l}0.0487^{* *} \\
(0.0221)\end{array}$ \\
\hline $\begin{array}{l}\geq 3 \text { years education after } \\
\text { high school }\end{array}$ & $\begin{array}{l}0.0438^{* *} \\
(0.0216)\end{array}$ & $\begin{array}{l}0.0609^{* * *} \\
(0.0214)\end{array}$ & $\begin{array}{l}0.0608^{* * *} \\
(0.0213)\end{array}$ & $\begin{array}{l}0.0497^{* *} \\
(0.0215)\end{array}$ & $\begin{array}{l}0.0495^{* *} \\
(0.0215)\end{array}$ & $\begin{array}{l}0.0370^{*} \\
(0.0217)\end{array}$ \\
\hline \multicolumn{7}{|l|}{ Family status } \\
\hline Single with children & $\begin{array}{l}-0.1086^{* * *} \\
(0.0347)\end{array}$ & $\begin{array}{l}-0.1091^{* * *} \\
(0.0347)\end{array}$ & $\begin{array}{l}-0.1089^{* * *} \\
(0.0347)\end{array}$ & $\begin{array}{l}-0.1069^{* * *} \\
(0.0347)\end{array}$ & $\begin{array}{l}-0.1070^{* * *} \\
(0.0347)\end{array}$ & $\begin{array}{l}-0.1073^{* * * *} \\
(0.0346)\end{array}$ \\
\hline $\begin{array}{l}\text { Married/cohabiting } \\
\text { without children }\end{array}$ & $\begin{array}{l}-0.0364^{* * *} \\
(0.0153)\end{array}$ & $\begin{array}{l}-0.0335^{* *} \\
(0.0154)\end{array}$ & $\begin{array}{l}-0.0329^{* *} \\
(0.0154)\end{array}$ & $\begin{array}{l}-0.0366^{* *} \\
(0.0154)\end{array}$ & $\begin{array}{l}-0.0362^{* *} \\
(0.0154)\end{array}$ & $\begin{array}{l}-0.0382^{* *} \\
(0.0153)\end{array}$ \\
\hline $\begin{array}{l}\text { Married/cohabiting with } \\
\text { children }\end{array}$ & $\begin{array}{l}-0.0492^{* * *} \\
(0.0156)\end{array}$ & $\begin{array}{l}-0.0468^{* * *} \\
(0.0157)\end{array}$ & $\begin{array}{l}-0.0465^{* * *} \\
(0.0157)\end{array}$ & $\begin{array}{l}-0.0486^{* * *} \\
(0.0156)\end{array}$ & $\begin{array}{l}-0.0484^{* * *} \\
(0.0156)\end{array}$ & $\begin{array}{l}-0.0501^{* * *} \\
(0.0156)\end{array}$ \\
\hline Other & $\begin{array}{l}-0.1266^{* * *} \\
(0.0618)\end{array}$ & $\begin{array}{l}-0.1218^{* * *} \\
(0.0620)\end{array}$ & $\begin{array}{l}-0.1220^{* *} \\
(0.0619)\end{array}$ & $\begin{array}{l}-0.1244^{* *} \\
(0.0619)\end{array}$ & $\begin{array}{l}-0.1244^{* *} \\
(0.0618)\end{array}$ & $\begin{array}{l}-0.1276^{* *} \\
(0.0617)\end{array}$ \\
\hline \multicolumn{7}{|l|}{ Housing } \\
\hline Rental & $\begin{array}{l}0.1231^{*} \\
(0.0684)\end{array}$ & $\begin{array}{l}0.1309^{*} \\
(0.0690)\end{array}$ & $\begin{array}{l}0.1299^{*} \\
(0.0688)\end{array}$ & $\begin{array}{l}0.1331^{*} \\
(0.0687)\end{array}$ & $\begin{array}{l}0.1322^{*} \\
(0.0686)\end{array}$ & $\begin{array}{l}0.1251^{*} \\
(0.0682)\end{array}$ \\
\hline Tenant-owned apartment & $0.1662^{* * *}$ & $0.1767^{* * *}$ & $0.1760^{* * *}$ & $0.1759^{* *}$ & $0.1752^{* *}$ & $0.1663^{* *}$ \\
\hline
\end{tabular}




\begin{tabular}{|c|c|c|c|c|c|c|}
\hline \multirow{3}{*}{ Single family home } & $(0.0684)$ & $(0.0689)$ & $(0.0687)$ & $(0.0687)$ & $(0.0685)$ & $(0.0681)$ \\
\hline & $0.1645^{* *}$ & $0.1745^{* *}$ & $0.1741^{* *}$ & $0.1749^{* * *}$ & $0.1745^{* *}$ & $0.1658^{* * *}$ \\
\hline & $(0.0683)$ & $(0.0688)$ & $(0.0687)$ & $(0.0686)$ & $(0.0685)$ & $(0.0681)$ \\
\hline \multirow[t]{2}{*}{ Constant } & $-2.1715^{* * *}$ & $-2.2407^{* * *}$ & $-2.2359^{* * *}$ & $-2.2359^{* * * *}$ & $-2.2372^{* * *}$ & $-2.1842^{* * * *}$ \\
\hline & $(0.1247)$ & $(0.1267)$ & $(0.1249)$ & $(0.1247)$ & $(0.1263)$ & $(0.1262)$ \\
\hline Pseudo R2 & 0.3086 & 0.3052 & 0.3054 & 0.3077 & 0.3078 & 0.3102 \\
\hline Log likelihood & -2140.93 & -2151.32 & -2150.81 & -2143.84 & -2143.35 & -2135.96 \\
\hline Observations & 6871 & 6871 & 6871 & 6871 & 6871 & 6871 \\
\hline
\end{tabular}


Table 10. Interaction of learning channels with financial literacy and portfolio shares in stocks

This table shows the estimates of the tobit regression of portfolio share in stocks on learning channel variables, financial literacy, the interactions of learning channels with financial literacy, and a set of controls. The dependent variable, portfolio share in stocks, is bounded at zero from below. Standard errors are reported in parentheses; ${ }^{* * *}$ $\mathrm{p}<0.01,{ }^{* *} \mathrm{p}<0.05,{ }^{*} \mathrm{p}<0.1$.

\begin{tabular}{lllll}
\hline Dependent variable: Share & $(1)$ & $(2)$ & $(3)$ & $(4)$ \\
\hline & & & & \\
Private network & 0.0020 & 0.0002 & 0.0013 & 0.0053 \\
& $(0.0048)$ & $(0.0032)$ & $(0.0032)$ & $(0.0049)$ \\
Financial advisor & -0.0032 & -0.0008 & -0.0020 & 0.0008 \\
& $(0.0032)$ & $(0.0048)$ & $(0.0032)$ & $(0.0048)$ \\
Media & $0.0098^{* * *}$ & $0.0097^{* * *}$ & -0.0028 & -0.0042 \\
& $(0.0034)$ & $(0.0034)$ & $(0.0051)$ & $(0.0052)$ \\
Private network $\times$ Financial literacy & -0.0033 & & & -0.0067 \\
& $(0.0062)$ & & & $(0.0062)$ \\
Financial advisor $\times$ Financial literacy & & -0.0042 & & -0.0049 \\
& & $(0.0063)$ & & $(0.0063)$ \\
Media $\times$ financial literacy & & & $0.0217^{* * *}$ & $0.0230^{* * *}$ \\
& & & $(0.0066)$ & $(0.0067)$ \\
Financial literacy & $0.0574^{* *}$ & $0.0610^{* *}$ & -0.0312 & 0.0029 \\
& $(0.0238)$ & $(0.0247)$ & $(0.0264)$ & $(0.0374)$ \\
Controls & & & & Yes \\
Pseudo R2 & Yes & Yes & Yes & 0.3123 \\
Log likelihood & 0.3103 & 0.3103 & 0.3120 & -2129.59 \\
Observations & -2135.82 & -2135.74 & -2130.48 & 6871 \\
\hline
\end{tabular}




\section{Appendix}

\section{Table A1}

Factor loadings for the six financial literacy questions. DK refers to "do not know."

\begin{tabular}{lll}
\hline & & $\begin{array}{l}\text { Factor } \\
\text { loadings }\end{array}$ \\
\hline How high is the Riksbank's inflation target? & Correct & 0.653 \\
& DK & -0.715 \\
$\begin{array}{ll}\text { If there is a risk that the inflation will exceed the inflation target, what should the } \\
\text { Riksbank do? }\end{array}$ & Correct & 0.607 \\
& DK & -0.719 \\
$\begin{array}{l}\text { If the nominal interest rate is 5\%, and the expected inflation is 2\%, how high will the } \\
\text { real interest rate be (approx.)? }\end{array}$ & Correct & 0.657 \\
& DK & -0.723 \\
$\begin{array}{l}\text { A savings product where you will receive a guaranteed amount at maturity, and the } \\
\text { return follows the equity market, is called }\end{array}$ & Correct & 0.605 \\
& DK & -0.656 \\
$\begin{array}{l}\text { Mutual funds have different risk levels; which of these mutual fund types is generally } \\
\text { viewed as having the highest risk? }\end{array}$ & Correct & 0.566 \\
& DK & -0.596 \\
The definition of the P/E-ratio is & Correct & 0.554 \\
& DK & -0.627 \\
\hline
\end{tabular}




\section{References}

Anderson, A., Baker, F., \& Robinson, D. T. (2017). Precautionary savings, retirement planning and misperceptions of financial literacy. Journal of financial economics, 126(2), 383-398.

Ausubel, D. P., Novak, J. D., \& Hanesian, H. (1968). Educational psychology: A cognitive view.

Balloch, A., Nicolae, A., \& Philip, D. (2015). Stock market literacy, trust, and participation. Review of Finance, 19(5), 1925-1963.

Berg, G., \& Zia, B. (2017). Harnessing emotional connections to improve financial decisions: Evaluating the impact of financial education in mainstream media. Journal of European Economic Association, 15(5), 1025-1055.

Biggs, J. B. (2011). Teaching for quality learning at university: What the student does. McGraw-hill education (UK).

Brown, J. R., Ivković, Z., Smith, P. A., \& Weisbenner, S. (2008). Neighbors matter: Causal community effects and stock market participation. Journal of Finance, 63(3), 1509-1531.

Changwony, F. K., Campbell, K., \& Tabner, I. T. (2015). Social engagement and stock market participation. Review of Finance, 19(1), 317-366.

Christelis, D., Jappelli, T., \& Padula, M. (2010). Cognitive abilities and portfolio choice. European Economic Review, 54(1), 18-38.

Christoffersen, S. E., Evans, R., \& Musto, D. K. (2013). What do consumers' fund flows maximize? Evidence from their brokers' incentives. The Journal of Finance, 68(1), 201-235.

Dougal, C., Engelberg, J., Garcia, D., \& Parsons, C. A. (2012). Journalists and the stock market. The Review of Financial Studies, 25(3), 639-679.

Egan M. (2019) Brokers vs. retail investors: Conflicting interests and dominated products. Journal of Finance 74(3):1217-1260.

Engelberg, J. E., \& Parsons, C. A. (2011). The causal impact of media in financial markets. The Journal of Finance, 66(1), 67-97.

Fernandes, D., Lynch Jr, J. G., \& Netemeyer, R. G. (2014). Financial literacy, financial education, and downstream financial behaviors. Management Science, 60(8), 1861-1883.

Foerster, S., Linnainmaa, J. T., Melzer, B. T., \& Previtero, A. (2017). Retail financial advice: does one size fit all? Journal of Finance, 72(4), 1441-1482.

Georgarakos, D., \& Inderst, R. (2014). Financial advice and stock market participation. ECB Working Paper.

Georgarakos, D., \& Pasini, G. (2011). Trust, sociability, and stock market participation. Review of Finance, 15(4), 693-725. 
Girshina, A., Mathä, T. Y., \& Ziegelmeyer, M. (2019). Peer effects in stock market participation: Evidence from immigration. ECB Working Paper

Granovetter, M. S. (1973). The strength of weak ties. American journal of sociology, 78(6), 1360-1380.

Granovetter, M. (2005). The impact of social structure on economic outcomes. Journal of economic perspectives, 19(1), 33-50.

Gunnarsson, J., and Wahlund, R. (1997). Household financial strategies in Sweden: An exploratory study. Journal of economic psychology, 18(2-3), 201-233.

Hackethal, A., M. Haliassos, and T. Jappelli (2012). Financial advisors: A case of babysitters?, Journal of Banking and Finance 36(2), 509- 524.

Haliassos, M., Jansson, T., \& Karabulut, Y. (2020). Financial literacy externalities. Review of Financial Studies, 33(2), 950-989.

Hastings, J. S., Madrian, B. C., \& Skimmyhorn, W. L. (2013). Financial literacy, financial education, and economic outcomes. Annual Review of Economics, 5, 347-373.

Hoechle, D., Ruenzi, S., Schaub, N., \& Schmid, M. (2018). Financial advice and bank profits. The Review of Financial Studies, 31(11), 4447-4492.

Hong, H., Kubik, J. D., \& Stein, J. C. (2004). Social interaction and stock-market participation. Journal of Finance, 59(1), 137-163.

Hu, L., Li, K., Ngo, P. T., \& Sosyura, D. (2020). Financial Media as a Money Doctor: Evidence from Refinancing Decisions. Working paper.

Inderst, R., \& Ottaviani, M. (2009). Misselling through agents. American Economic Review, 99(3), 883-908.

Jappelli, T., \& Padula, M. (2013). Investment in financial literacy, social security and portfolio choice (No. 2013/12). CFS Working Paper.Kramer, M. M. (2012). Financial advice and individual investor portfolio performance. Financial Management, 41(2), 395-428.

Kramer, M. M. (2016). Financial literacy, confidence and financial advice seeking. Journal of Economic Behavior \& Organization, 131, 198-217.

Liang, P., \& Guo, S. (2015). Social interaction, Internet access and stock market participation-An empirical study in China. Journal of Comparative Economics, 43(4), 883901.

Liao, L., Xiao, J. J., Zhang, W., \& Zhou, C. (2017). Financial literacy and risky asset holdings: evidence from China. Accounting \& Finance, 57(5), 1383-1415.

Lusardi, A. (2008). Financial literacy: an essential tool for informed consumer choice? (No. w14084). National Bureau of Economic Research. 
Lusardi, A. (2012). Numeracy, financial literacy, and financial decision-making (No. w17821). National Bureau of Economic Research.

Lusardi, A. (2019). Financial literacy and the need for financial education: evidence and implications. Swiss Journal of Economics and Statistics, 155(1), 1-8.

Lusardi, A., Schneider, D., Tufano, P., Morse, A., and Pence, K.M. (2011). Financially fragile households: Evidence and implications (with comments and discussion). Brookings Papers on Economic Activity, 83-150

Mullainathan, S., Noeth, M., \& Schoar, A. (2012). The market for financial advice: An audit study (No. w17929). National Bureau of Economic Research.

Peress, J. (2014). The media and the diffusion of information in financial markets: Evidence from newspaper strikes. The Journal of Finance, 69(5), 2007-2043.

Tobias, S. (1994). Interest, prior knowledge, and learning. Review of educational Research, 64(1), 37-54.

Van Rooij, M., Lusardi, A., \& Alessie, R. (2011). Financial literacy and stock market participation. Journal of Financial Economics, 101(2), 449-472.

Von Gaudecker, H. M. (2015). How does household portfolio diversification vary with financial literacy and financial advice, 70(2) Journal of Finance, 489-507.

Willis, L. E. (2011). The financial education fallacy. American Economic Review, 101(3), 42934.

Xia, T., Wang, Z., \& Li, K. (2014). Financial literacy overconfidence and stock market participation. Social indicators research, 119 (3), 1233-1245.

Yoong, J. (2011). Financial illiteracy and stock market participation: Evidence from the RAND American Life Panel. Financial literacy: Implications for retirement security and the financial marketplace, 76. 